\title{
Lamprophyres from the Indian shield: A review of their occurrence, petrology, tectonomagmatic significance and relationship with the Kimberlites and related rocks
}

\author{
EPMA and SEM laboratories, Department of Geology, Institute of Science, Banaras Hindu University, Varanasi-221005, India \\ (*Corresponding author, Email: nvcrao@bhu.ac.in)
}

(Received : 30/04/2019; Revised accepted : 27/11/2019)

https://doi.org/10.18814/epiiugs/2020/020014

Lamprophyres are some of the oldest recognized alkaline rocks and have been studied for almost the last 150 years. Known for hosting economic minerals such as gold, diamond and base metals, they are also significant in our understanding of the deep-mantle processes (viz., mantle metasomatism and mantleplume-lithosphere interactions) as well as large-scale geodynamic processes (viz., subduction-tectonics, supercontinent amalgamation and break-up). The Indian shield is a collage of distinct cratonic blocks margined by the mobile belts and manifested by large igneous provinces (LIPs) such as the Deccan. A plethora of lamprophyres, varying in age from the Archaean to the Eocene, with diverse mineralogical and geochemical compositions, are recorded from the Indian shield and played a key role in clarifying the tectonic processes, especially during the Paleo- and Mesoproterozoic and the Late Cretaceous. A comprehensive review of the occurrence, petrology, geochemistry and origin of the Indian lamprophyres is provided here highlighting their tectonomagmatic significance. The relationship of the lamprophyres to the Kimberlite clan rocks (KCRs), focusing on the Indian examples, is also critically examined.

\section{Introduction}

Lamprophyre (derived from Greek word lampros porphyrous meaning 'glistening porphyry') is basically a field term introduced by Von Gümbel in 1874 representing its diagnostic character. Lamprophyres, for long, have been misinterpreted and confused with porphyritic varieties of igneous rocks (viz., basalts and andesites) and were considered to be 'impossible to classify' igneous rocks and treated as 'obscure petrological curiosities'. The most remarkable and distinguishing works in the field of lamprophyres were carried out by late N.M.S. Rock. In a series of papers (summarized in Rock, 1991), he focused the petrological attention towards this very significant rock-type, which was considered until then to be enigmatic. Lamprophyres are currently defined as the mantle-derived maficultramafic volatile-rich alkaline igneous rocks characterized by porphyritic-panidiomorphic texture with phenocrysts of hydrous mafic silicates such as amphibole and mica with feldspars, where recognizable, are always restricted to the groundmass (Rock, 1991).

Although these rocks are volumetrically insignificant $(<1 \%)$, they have profound implications for understanding enrichment and depletion processes in the sub-continental lithospheric mantle (SCLM, e.g., Guo et al., 2004; Krmíček et al., 2011, 2016; Abdelfadil et al., 2013) and large scale-geodynamic processes (e.g., Tappe et al., 2006; Ulrych et al., 2014; Pandey et al., 2017a). Lamprophyres, together with other deep mantle-derived rocks such as kimberlites, lamproites and alkali basalt, are essentially restricted to the continental plates and their geochemistry provide invaluable clues with regard to probing the nature and evolution of the underlying mantle domains. Owing to very high contents of incompatible trace elements in primary lamprophyre magma, the assimilation of continental crust is insignificant in controlling the abundance of these elements and therefore, these rocks retain geochemical memories of mantle source regions. Some of the lamprophyres are known to be diamondiferous and some are also associated with the mesothermal gold-copper deposits (Wyman et al., 2006; Muller and Groves, 2019) and hence of economic significance. The mantle- and crustal-xenoliths and xenocrysts often entrained in lamprophyre magmas also constitute direct samples to understand the nature of the earth's continental plates (Dostal et al., 2005; Orejana et al., 2006).

International Union of Geological Sciences (IUGS) has recommended classification of the lamprophyres into three broad categories: (i) alkaline lamprophyres, which are considered as the hydrous equivalents of basalts from the divergent margins (e.g., Orejana et al., 2008; Batki et al., 2014; Stoppa et al., 2014), (ii) calcalkaline lamprophyres, which are essentially associated with convergent settings and hence carry 'crustal' geochemical signature (e.g., Luhr et al., 1989; Owen, 2008; Garza et al., 2013; Pandey et al., 2017a, 2018b), and (iii) ultramafic lamprophyres, which are associated 
with the regions of lithospheric extension, continental rifting and continental break-up (e.g., Delor and Rock, 1991; Andronikov and Foley, 2001; Foley et al., 2002; Tappe et al., 2004, 2006; Nasir, 2016; Pandey et al., 2018a).

In the Indian shield, lamprophyres have been reported from various cratons, mobile belts and large igneous provinces viz., the Eastern Dharwar Craton (EDC), the Mahakoshal supracrustal belt and the Sidhi alkaline complex in the Central Indian Tectonic Zone, the Gondwana coalfield and the Deccan large igneous province. In this paper, we review the lamprophyre magmatism from the Indian shield in space and time in terms of their occurrences, nature of the mantle source regions and geodynamic setting. We also venture to critically examine their relationships with the co-spatial and co-eval kimberlite clan rocks (KCRs).

\section{Distribution of lamprophyres in India}

The occurrences of lamprophyres from the Indian shield (Fig. 1) along with their available emplacement ages have been compiled in

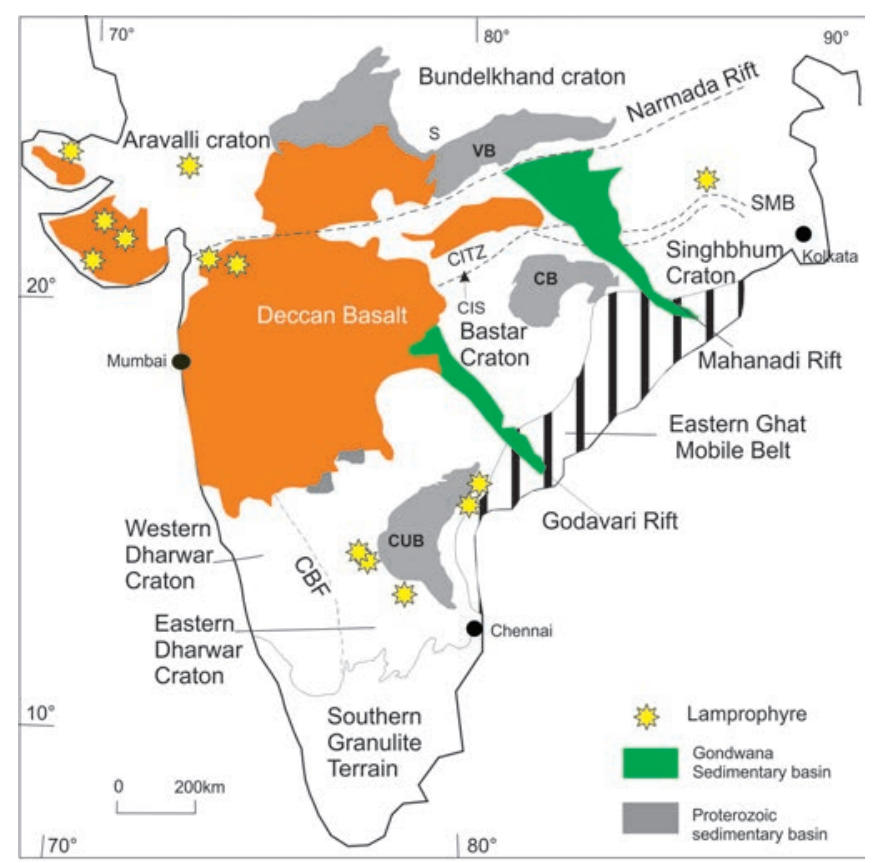

Figure 1. A generalized geological map of the peninsular India (Naqvi, 2005) showing locations of the lamprophyres reported from the Indian Shield.

Table 1. Some representative field photographs, photomicrographs depicting mineralogy and textures of Indian lamprophyres are also provided in Fig. 2. Broadly, the lamprophyre occurrences can be divided into the following four groups (see also Paul, 1991):

Group 1: Occurrences in the Archaean and Paleo-Mesoproterozoic schist belts e.g., Nuggihalli (Western Dharwar craton), Kadiri (Eastern Dharwar craton), and Jungel valley, Mahakoshal belt (Central Indian tectonic zone).

Group 2: In the Precambrian granite-gneissic terrain as isolated dykes or as clusters e.g., Udiripikonda, Korakkodu, (Eastern Dharwar craton), Sidhi (Central Indian Tectonic zone).

Group 3: Associated with the Meso-Neoproterozoic alkaline complexes e.g., Elchuru, Purimetala (Prakasam Alkaline Province), Pikkili (Southern Granulite Terrain).

Group 4: Associated spatially and temporally with the Early- and Late Cretaceous large igneous provinces viz., the lamprophyres from the Deccan Traps and the Gondwana coalfield (Rajmahal Traps).

Overall, the Eastern Dharwar Craton (EDC) hosts the maximum number of lamprophyre dykes all around the Paleo-Mesoproterozoic Cuddapah Basin. All these lamprophyres are of Mesoproterozoic in age. The Western Dharwar Craton (WDC) is known to be barren in terms of alkaline magmatism, unlike its eastern counterpart. However, Sugavanam et al. (1994) have reported the occurrence of Archean meta-lamprophyres from the Nuggihalli greenstone belt. The Southern Granulite Belt hosts numerous Neoproterozoic lamprophyres that are co-eval with the shonkinites, syenites and carbonatites and associated with the alkaline complexes. Recently, Meshram et al. (2018) have reported calc-alkaline lamprophyres from the Thaneswana area, the western part of the Bastar Craton. A number of presumably Meso- to Neoproterozoic lamprophyres are also hosted in the AravalliBundelkhand and Singhbhum Craton, which have been comparatively far less studied and their petrogenetic and geodynamic significance remains unexplored. Various lamprophyre dykes of Paleoproterozoic and Late Cretaceous have also been reported from the Mahakoshal supracrustal belt and Sidhi alkaline complex, in the Central India Tectonic Zone. The youngest of the lamprophyres in the Indian shield are those associated spatially with the Deccan Large Igneous Province. The Deccan lamprophyres range in age from Early to Late Cretaceous and predate, synchronous with as well as postdate the Cretaceous main flood basalt eruption ( $\sim 5 \mathrm{Ma}$.). In the following sections, we review the mineralogical and geochemical characters of important lamprophyre clusters of the Indian shield along with their tectonic implications.

\section{Eastern Dharwar Craton lamprophyres}

The lamprophyres in the Eastern Dharwar Craton (EDC) are exposed in two-broad domains: (i) the Prakasam Alkaline Province (PAP) towards the east of the Cuddapah Basin at the junction of the EDC and Eastern Ghats Mobile Belt (EGMB), and (ii) towards the western margin of the Cuddapah Basin within the Eastern Dharwar Craton (Fig. 1).

The PAP lamprophyres constitute those exposed at Elchuru, Settupalle, Kommalapadu, Purimetla, Pasupugallu, Kellampalle, and Ravipadu, and have intruded a variety of host rocks including nepheline- and quartz-syenites, gabbro and granites (Madhavan et al., 1998 and references therein). These lamprophyres are meso- to melanocratic and constitute phenocrysts of clinopyroxene and olivine with biotite, plagioclase and orthoclase confined to the groundmass, classifying them as alkaline lamprophyres in general and camptonites in particular (Madhavan et al., 1998 and references therein). The Kellampalle lamprophyre, which is a plug-like body covering an area of about five square meters unlike other dyke exposures, has phenocrysts of amphibole and classified as sannaite variety (Ratnakar et al., 1992, 1996). An interesting feature of the lamprophyres exposed at Settupalle, Purimetla and Kellampalle is the presence of ocellar structure that constitute of minerals like analcite, cancrinite and nepheline, which are otherwise absent in the host rock (Leelanandam and Ratnakar, 1980; Leelanandam and Srinivasan, 1986; Ratnakar et al., 1992). Clinopyroxene is ubiquitous in these lamprophyres and compositionally a salite (Madhavan et al., 1998). These 
Table 1. Distribution and age of lamprophyres from the Indian shield (updated after Chalapathi Rao, 2008).

\begin{tabular}{|c|c|c|c|c|}
\hline & Locality & Lamprophyre type & Age & Important References \\
\hline \multicolumn{5}{|c|}{ Eastern Dharwar craton (EDC) } \\
\hline 1 & Elchuru & minette, sannaite, tjosite, damkjernite & $\begin{array}{l}1242 \pm 33 \mathrm{Ma} \\
1321 \mathrm{Ma}\end{array}$ & $\begin{array}{l}\text { Subba Rao et al. (1989); Madhavan et al. (1992); } \\
\text { Upadhyay et al. (2007); }\end{array}$ \\
\hline 2 & Purimetla & sannaite, camptonite & Mesoproterozoic & Leelanandam and Ratnakar (1980) \\
\hline 3 & Settupalle & camptonite & Mesoproterozoic & Leelanandam and Srinivasan (1986) \\
\hline 4 & Pasupugallu & camptonite & Mesoproterozoic & Madhavan et al. (1998) \\
\hline 5 & Kommalapadu & camptonite & Mesoproterozoic & Madhavan et al. (1998) \\
\hline 6 & Kellampalle & sannaite & Mesoproterozoic & Ratnakar et al. (1996) \\
\hline 7 & Ravipadu & camptonite & Mesoproterozoic & Ratnakar et al. (1995) \\
\hline 8 & Yachenahalli & spessartite, vogesite & Mesoproterozoic & Raghunatha Rao (1939) \\
\hline 9 & Polayapalle & minette & Mesoproterozoic & Subrahmanyam et al. (1987) \\
\hline 10 & Garla-Khammam & minette & Mesoproterozoic & Appavadhanulu (1971) \\
\hline 11 & Kushalnagar & camptonite & Mesoproterozoic & Rock and Paul (1989) \\
\hline 12 & Bayyaram & camptonite & Mesoproterozoic & Meshram et al. (2015) \\
\hline 13 & Kadiri & spessartite & Mesoproterozoic & Pandey et al. (2018a) \\
\hline 14 & Mudigubba & spessartite & $1169 \mathrm{Ma}$ & Pandey et al. (2017a); unpublished data \\
\hline 15 & Udiripikonda & kersanite & Mesoproterozoic & Pandey et al. (2017b) \\
\hline 16 & Korakkodu & kersantite & Mesoproterozoic & Raghuvanshi et al. (2019) \\
\hline 17 & Harohalli & spessartite, vogesite & Neoproterozoic & Lanjewar and Randive (2017); Devaraju et al.(1995) \\
\hline \multicolumn{5}{|c|}{ Western Dharwar craton (WDC) } \\
\hline 1 & $\begin{array}{l}\text { Kempinkote, Nuggihalli } \\
\text { Schist belt }\end{array}$ & meta-lamprophyre & Archaean & Sugavanam et al. (1994) \\
\hline \multicolumn{5}{|c|}{ Southern Granulite Terrain (SGT) } \\
\hline 1 & Pikkili & camptonite & 700-800 Ма & Navaneethakrishnan and Chandrasekharan (1994) \\
\hline 2 & Tiruppattur & vogesite & $700-800 \mathrm{Ma}$ & Saravanan and Ramasamy (1995); Rock and Paul (1989) \\
\hline \multicolumn{5}{|c|}{ Bastar craton (BC) } \\
\hline 1 & Thanewasna & minette & Mesoproterozoic & Meshram et al. (2018) \\
\hline \multicolumn{5}{|c|}{ Aravalli-Bundelkhand craton } \\
\hline 1 & Pipela & meta-lamprophyre & $1.5-0.85 \mathrm{Ga}$ & $\begin{array}{l}\text { Fareeduddin et al. (1995); } \\
\text { Kirmani and Fareeduddin (2000) }\end{array}$ \\
\hline 2 & Kishangarh & camptonite & Precambrian & Rock and Paul (1989) \\
\hline \multicolumn{5}{|c|}{ Singhbhum-Eastern India craton and Meghalaya } \\
\hline 1 & Singhbhum & spessartite & Precambrian & Sinha et al. (1973); Saha et al. (1973) \\
\hline 2 & Simdega & & Precambrian & Singh et al. (2004) \\
\hline 3. & $\begin{array}{l}\text { East Garo Hills and West } \\
\text { Khasi Hills, Meghalaya }\end{array}$ & $\begin{array}{l}\text { camptonite, } \\
\text { monchiquite }\end{array}$ & $107 \mathrm{Ma}$ & Nambiar $(1988,2007)$ \\
\hline \multicolumn{5}{|c|}{ Central Indian Tectonic Zone, Mahakoshal Supracrustals } \\
\hline 1 & Jungel & Meta-lamprophyre & $1.6 \mathrm{Ga}$ & Nair et al. (1995); Srivastava and Chalapathi Rao (2007) \\
\hline 2 & Chitrangi & aillikite & $1.6 \mathrm{Ga}$ & Srivastava (2013) \\
\hline 3 & Sidhi & minette & $97 \mathrm{Ma}$ & Paul and Potts (1981); Paul and Sarkar (1984) \\
\hline \multicolumn{5}{|c|}{ Damodar valley (Rajmahal Traps) } \\
\hline 1. & $\begin{array}{l}\text { Gondwana coal fields (Jharia, } \\
\text { Raniganj, Bokaro etc) }\end{array}$ & $\begin{array}{l}\text { aillikite-orangeite-kimberlite } \\
\text { transitional type }\end{array}$ & $117 \mathrm{Ma}$ & $\begin{array}{l}\text { Sarkar et al. (1980); Kent et al (1998); } \\
\text { Chalapathi Rao et al (2014) }\end{array}$ \\
\hline \multicolumn{5}{|c|}{ Kutch and the Deccan Traps } \\
\hline 1 & Murud Janjira & $\begin{array}{l}\text { camptonite, } \\
\text { monchiquite }\end{array}$ & $64.9 \pm 0.8 \mathrm{Ma}$ & $\begin{array}{l}\text { Deshpande and Chakranarayan (1973); } \\
\text { Sahu et al (2003); Desai and Viegas (2010) }\end{array}$ \\
\hline 2 & $\begin{array}{l}\text { Chhota Udepur, Seraphalia, } \\
\text { Piliwat, Panwad, Moradungri, } \\
\text { Jitnagar, Kanthari, Heran, } \\
\text { Hamirpur, Dongargaon }\end{array}$ & $\begin{array}{l}\text { kersantite, sannaite, } \\
\text { vogesite, alnoite, } \\
\text { damtjernite, } \\
\text { camptonite }\end{array}$ & 65 to $55 \pm 2 \mathrm{Ma}$ & $\begin{array}{l}\text { Gwalani et al (1993); Chawade (1996); } \\
\text { Srikarni and Sanjay Das (2005); } \\
\text { Chalapathi Rao et al. (2012); Randive et al (2012); } \\
\text { unpublished data; Pandey et al. (2019) }\end{array}$ \\
\hline 3 & Palanpur & damtjernite & $124 \mathrm{Ma}$ & Karmallkar et al(2014); Pandey et al.(2017) \\
\hline 4 & $\begin{array}{l}\text { Parol, Bassein district; } \\
\text { Trombay island, Bombay }\end{array}$ & camptonite & Late Cretaceous & Sukeshwala and Sethna (1962) \\
\hline 5 & Phenai Mata & camptonite & Late Cretaceous & Sadashivaiah and Durgadmath (1976) \\
\hline 6 & Chaktalao & camptonite, kersantite & Late Cretaceous & Chawade (1996); Hari (1998) \\
\hline 7 & Mount Girnar & $\begin{array}{l}\text { monchiquite,camptonite, } \\
\text { vogesitespessartite }\end{array}$ & $\begin{array}{l}69.1 \pm 1.17 \mathrm{Ma} \\
\text { to } 56.2 \mathrm{Ma}\end{array}$ & $\begin{array}{l}\text { Evans (1901); Subba Rao (1971); } \\
\text { Paul et al. (1977); Rathore et al (1996) }\end{array}$ \\
\hline 8 & Mundwara & $\begin{array}{l}\text { minette, camptonite, } \\
\text { vogesite }\end{array}$ & $\begin{array}{l}68.53 \pm 0.16 \mathrm{Ma} \\
80-110 \mathrm{Ma}\end{array}$ & $\begin{array}{l}\text { Basu et al. (1993); Yadava and } \\
\text { Karkare (1975); Pande et al. (2016) }\end{array}$ \\
\hline 9. & Nir-Wandh & sannaite, camptonite & $67 \mathrm{Ma}$ & Jaitly et al (1980); Paul et al. (2008); Ray et al (2014) \\
\hline
\end{tabular}


Figure 2. Field photographs and photomicrographs of some Indian lamprophyres. (A) A lamprophyre dyke in the Gondwana coal fields (Chhoti Nadi) exposed in a river cutting; (B) A shoshonitic lamprophyre dyke intruding the country rock granite in the Wajrakarur kimberlite field at Udiripikonda in the Eastern Dharwar Craton; (C) A cross-cutting lamprophyre in a syenite at Moradongari in the Chhotaudepur sub-alkaline province in the Deccan LIP. The syenite itself intrudes the Deccan Traps; (D) A calc-alkaline lamprophyre from Mudigubba, Eastern Dharwar Craton. Big amphibole phenocrysts impart a porphyritic texture on a megascopic scale; (E) The Chhotaudepur lamprophyre in the Deccan LIP displaying particularly large amphibole phenocrysts; (F) A composite dyke of lamprophyre and nepheline syenite in the Girnar alkaline complex, Deccan LIP. (G) Phlogopite-rich lamprophyric dyke in the Gondwana coal fields (Raniganj) PPL; (H) Abundance of amphibole and clinopyroxene phenocrysts in the Mudigubba Iamprophyre, Eastern Dharwar Craton (XPL); (I) A clinopyroxene phenocryst showing corroded margin in the Udiripikonda shoshonitic lamprophyre, Eastern Dharwar Craton (PPL); (J) Bimodal distribution of olivine and clinopyroxene phenocrysts in the Seraphalia lamprophyre, Deccan LIP (PPL); (K) Zoned amphibole and biotite phenocrysts in the Dongargaon lamprophyre, Deccan LIP (PPL); (L) Phenocryst of clinopyroxene from the Purimetla area Prakasam alkaline province
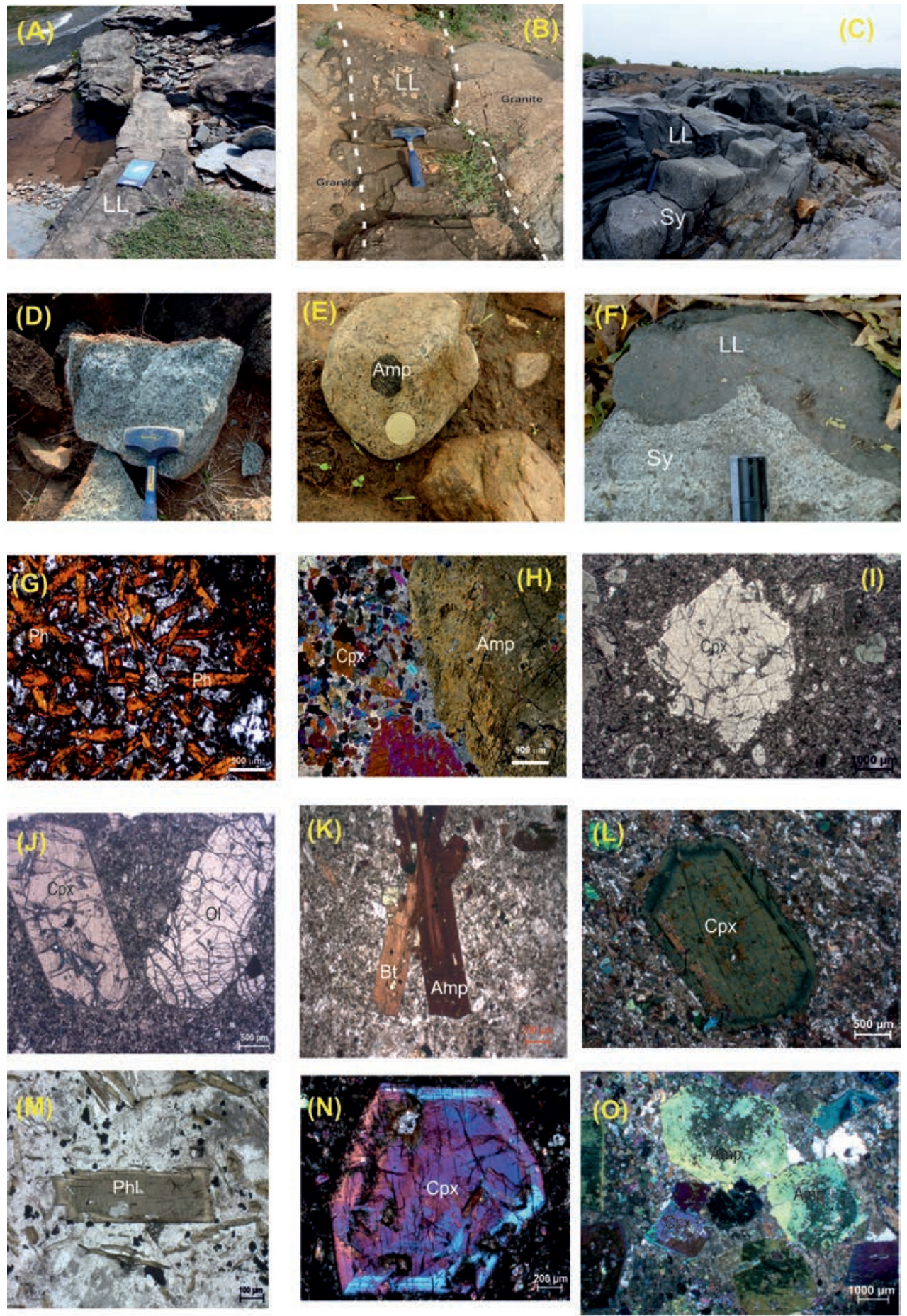

(XPL); (M) Zoned phlogopite phenocryst from the Sidhi lamprophyres of CITZ showing reverse pleochroism (PPL). (N) Zoned euhedral phenocryst of clinopyroxene from the Udiripikonda shoshonitic lamprophyre, Eastern Dharwar Craton (in XPL); (O) Clusters of amphibole phenocrysts from Mudigubba lamprophyre showing panidiomorphic- porphyritic- glomerophyric texture (in PPL). Abbreviations: Am=

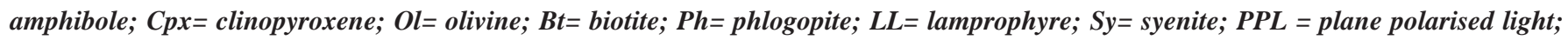
$X P L=$ crossed polarised light.

clinopyroxenes are characterized by depletion in $\mathrm{TiO}_{2}$ akin to that of orogenic alkaline magmatic rocks (Fig. 3). Biotite is another common mineral with $\mathrm{Al}_{2} \mathrm{O}_{3}$ content much higher than that in the lamproites, similar to those exhibited by the alkaline (AL) and calc-alkaline lamprophyres (CAL) (Fig. 4). A conspicuous feature of the olivines from the Kommalapadu lamprophyres is that they are exceptionally fayalitic $\left(\mathrm{Fo}_{28}\right)$ unlike global lamprophyres (Madhavan et al., 1998). The bulk-rock total alkalis $\left(\mathrm{Na}_{2} \mathrm{O}+\mathrm{K}_{2} \mathrm{O}\right)$ of the PAP lamprophyres varies between 4.1 and 9.26 (Madhavan et al., 1998; Vijaya Kumar and Rathna, 2008) and the $\mathrm{K}_{2} \mathrm{O} / \mathrm{Na}_{2} \mathrm{O}$ ranging between 0.5 and 2, and highlights their affinity with the shoshonitic volcanics (Fig. 6a). Shoshonitic lamprophyres are those with mixed affinities to the calcalkaline (orogenic) and alkaline (anorogenic) lamprophyres, which are well exhibited for these lamprophyres on a $\mathrm{SiO}_{2}$ vs. $\mathrm{K}_{2} \mathrm{O}$, diagram (Fig. 6b). This observation is further corroborated by their deficiency in silica content alike the alkaline lamprophyres yet displaying potassic 


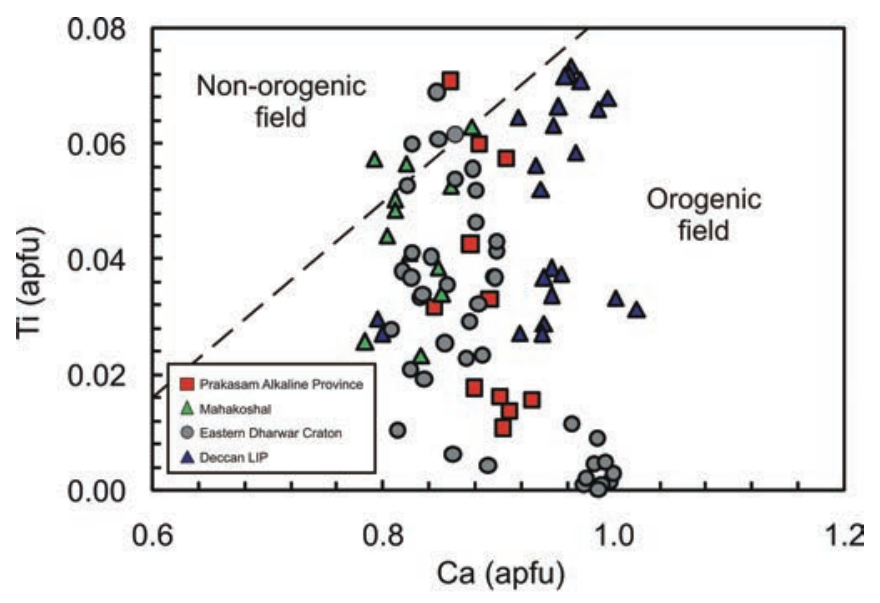

Figure 3. Ti (a.p.f.u) vs Ca (a.p.f.u) plot (after Sun and Bertrad, 1991) of clinopyroxenes from Indian lamprophyres. Data Sources: Prakasam Alkaline Province (Madhavan et al., 1998; Madhavan et al., 1992; Upadhyay et al., 2006; Vijaya Kumar and Rathna, 2008); Deccan LIP (Hari et al., 1998; Chalapathi Rao et al., 2012; Melluso et al., 2012; Dessai and Vegas, 2010; Pandey et al., 2017c); Mahakoshal (Srivastava and Chalapathi Rao, 2007; Srivastava, 2013) Gondwana Coalfield (Srivastava et al., 2009; Chalapathi Rao et al., 2014); Eastern Dharwar Craton (Meshram et al., 2015, Pandey et al., 2018b, Pandey et al., 2017a, b; Lanjewar and Randive, 2017).

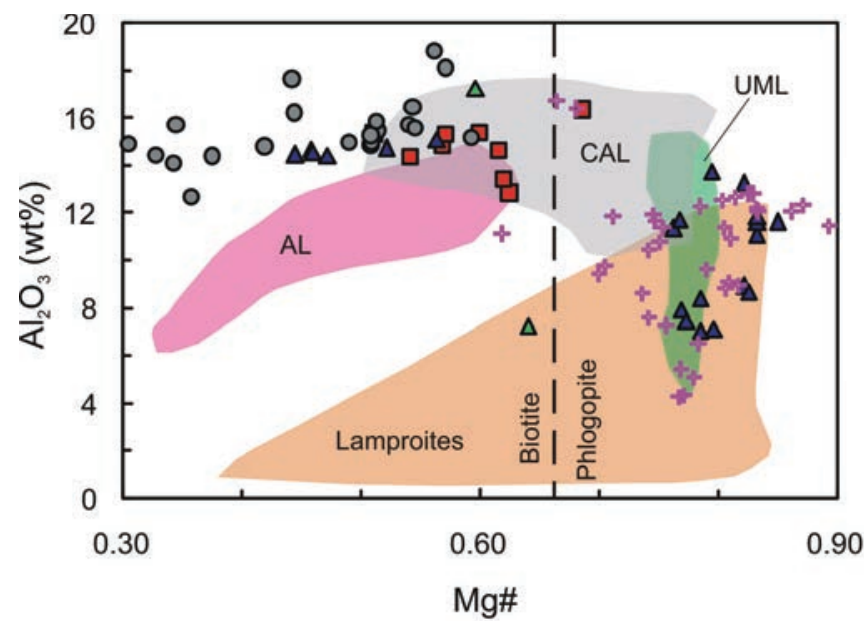

$\square$ Prakasam Alkaline Province

$\triangle$ Mahakoshal

Eastern Dharwar Craton

$\Delta$ Deccan LIP

* Gondwana coal field

Figure 4. $\mathrm{Mg \#}$ vs $\mathrm{Al}_{2} \mathrm{O}_{3}$ (wt \%) variation diagram (after Rock, 1986) classifying the mica based on $\mathrm{Mg} / \mathrm{Fe}^{(\mathrm{II})}$ ratio and lamprophyres into CAL (calc-alkaline), AL (alkaline), UML (ultramafic). Data sources are same as in Fig. 3.

nature portrayed by the calc-alkaline lamprophyres (Rock, 1991). According to Madhavan et al. (1998), these lamprophyres correspond to a mixed affinity to the CAL and AL in terms of trace element concentrations with their $\mathrm{V}, \mathrm{Cr}$, and Hf contents being similar to the average $\mathrm{CAL}$ and $\mathrm{Co}$, Ga and REE abundances are indistinguishable from that of the average AL. A restricted range in the major oxide composition variation for these lamprophyres suggests they are likely to be a part of a single magmatic episode.

Subba Rao et al. (1989) have reported Rb-Sr isochron age of the

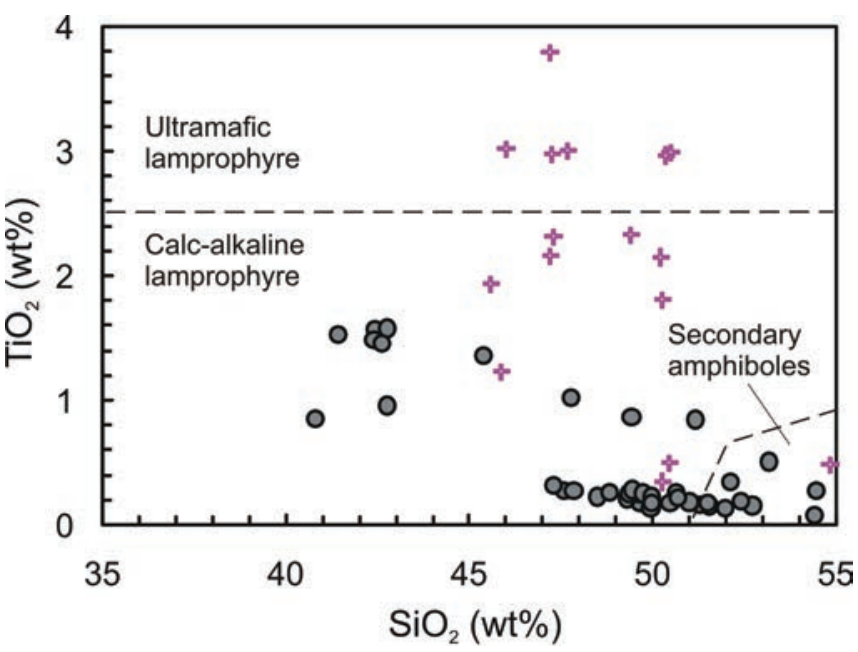

Figure 5. $\mathrm{TiO}_{2}$ (wt \%) vs $\mathrm{SiO}_{2}$ (wt \%) plot comparing amphibole chemistry of the Indian lamprophyres with the worldwide calcalkaline and ultramafic lamprophyres (after Rock, 1991). Data sources are same as in Fig. 3.

lamprophyres and other associated rocks from Elchuru to be $1242 \pm 33$ Ma. The chondrite-normalized rare earth elements pattern is very steep because of highly fractionated light and heavy rare earth elements (LREE and HREE, respectively). A negative trough for potassium on the chondrite-normalized multielement diagram is common in all these lamprophyres, which along with depletion in Sr content for the Polayapalle lamprophyre correspond to the presence of phlogopite in their mantle source regions (see Madhavan et al., 1998). Although, Madhavan et al. (op. cit.) have advocated a primary nature of these lamprophyres based on $\mathrm{Mg \# ,} \mathrm{Ni}$ and $\mathrm{Cr}$ contents, they have highly variable $\mathrm{Nb} / \mathrm{U}$ and $\mathrm{Ce} / \mathrm{Pb}$ ratios offsetting from the mantle array defined by the MORBs and OIBs (Fig. 7). However, they are characterized by higher $\mathrm{Th} / \mathrm{Yb}$ and $\mathrm{Nb} / \mathrm{Yb}$ ratios similar to those of the OIBs (Fig. 8). It is clear from these trace element ratios, that these shoshonitic lamprophyres show dual geochemical traits of orogenic as well as anorogenic alkaline volcanics. Such a mixed character can be explained by two-stage metasomatism, wherein the early stage is characterized by a subduction-accretion related metasomatism of the mantle edge, followed by the SCLM metasomatism by asthenospheric melts/fluids. This model is also invoked to explain the genesis of shoshonitic lamprophyres from the EDC, which also show mixed orogenic-anorogenic characters (Pandey et al., 2017b).

The lamprophyres towards the western margin of the Cuddapah Basin are exposed at (i) the Mudigubba, (ii) in the Wajrakarur kimberlite field, and (iii) the Kadiri schist belt (Fig. 1; Pandey et al., 2017a, b, 2018b; Khan et al., 2018). These lamprophyres can be compositionally grouped into two groups: (i) calc-alkaline lamprophyres (CALs) at Mudigubba and Kadiri, and (ii) shoshonitic lamprophyres, which are co-eval and co-spatial with the kimberlites from the Wajrakarur kimberlite field as at Udiripikonda, Sivarampeta and Korakkodu. These calc-alkaline lamprophyres are characterized by the presence of amphibole phenocrysts, which are essentially classified as magnesio-hornblende. These amphiboles are depleted in the $\mathrm{TiO}_{2}$ content that is consistent with their calc-alkaline nature (Fig. 5). Some of these amphiboles are rich in silica and are classified as actinolite, which are rarely found in the igneous rocks and are characteristics of the low-grade metamorphic rocks. Pandey et al. (2017a) explained them to be a result of auto-metamorphism given 
the fact that lamprophyres are hydrous melts and capable of altering the composition of their mafic phenocrysts. Pyroxenes are confined only to the Mudigubba CALs and are absent in the Kadiri CALs. The pyroxenes can be essentially classified as diopside. Mica is absent in the CALs exposed at Mudigubba but form an important constituent in the Kadiri lamprophyres supplementing their bulk-rock $\mathrm{K}_{2} \mathrm{O}$ content (Pandey et al., 2018b). These micas are classified as biotite and are compositionally comparable to those observed from CALs worldwide (Fig. 4).

Based on the bulk-rock $\mathrm{K}_{2} \mathrm{O}$ and $\mathrm{Na}_{2} \mathrm{O}$ abundances also, these rocks are classified as calc-alkaline variety (Fig. 6). An important geochemical trait exhibited by these lamprophyres is the conspicuous negative anomalies at $\mathrm{Nb}$, Ta, $\mathrm{Zr}$, Hf and $\mathrm{Ti}$ on primitive mantle normalized multi-element diagram, which are considered to be
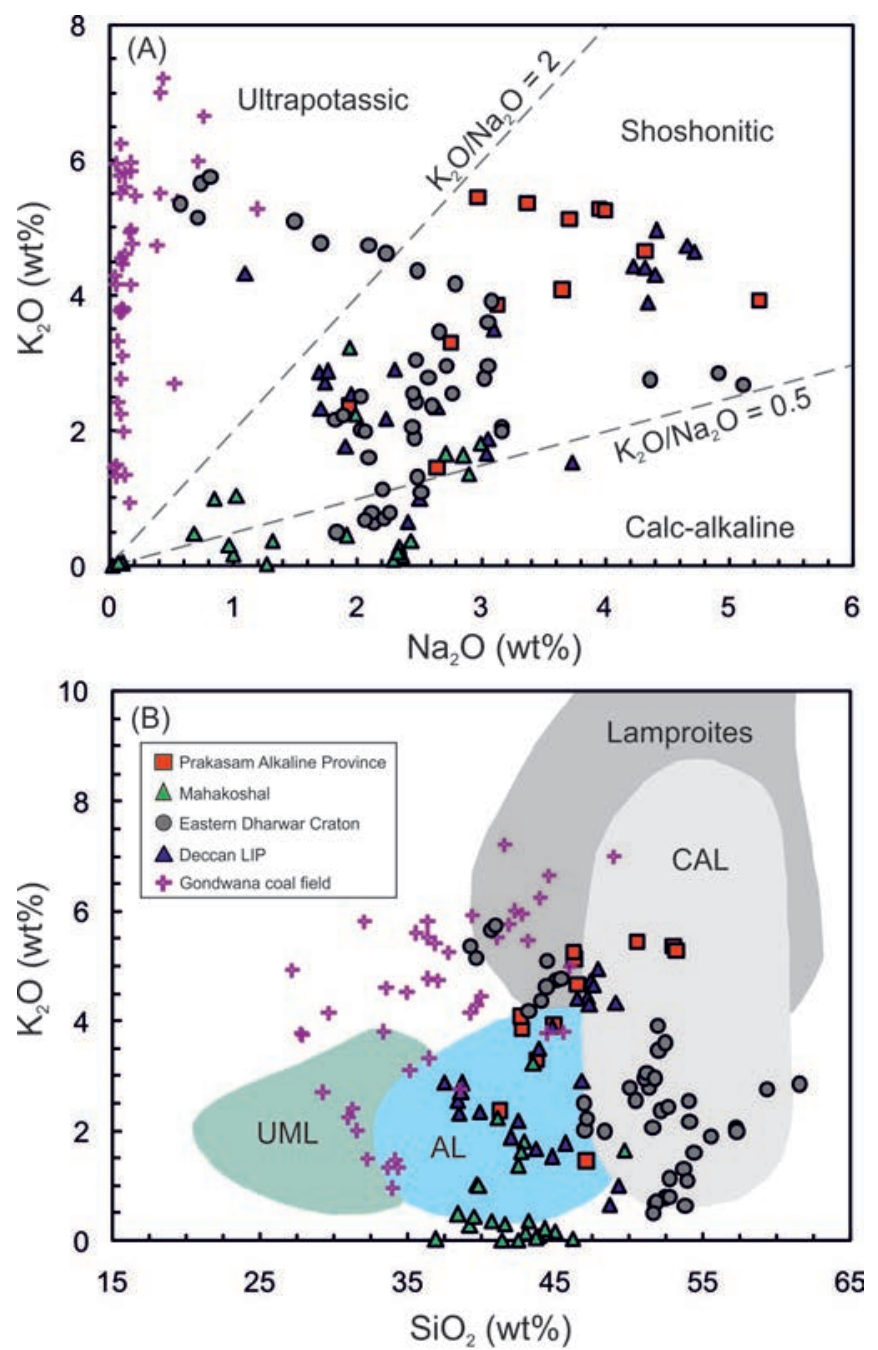

Figure 6. (A) $\mathrm{Na}_{2} \mathrm{O}$ (wt\%) vs. $\mathrm{K}_{2} \mathrm{O}(w t \%)$ and (B) $\mathrm{SiO}_{2}(w t \%)$ vs. $\mathrm{K}_{2} \mathrm{O}$ (wt\%) (after Rock, 1987) plots classifying the lamprophyres from the Indian shield. Data sources: Prakasam Alkaline Province (Subrahmanyam et al., 1987; Madhavan et al., 1992, 1998; Ratnakar et al., 1996; Vijaya Kumar and Rathna, 2008), Mahakoshal (Srivastava and Chalapathi Rao, 2007; Srivastava, 2013), Eastern Dharwar Craton (Meshram et al., 2015; Lanjewar and Randive, 2017; Pandey et al., 2017a, b, 2018b), Deccan LIP (Dessai and Vegas, 2010; Chalapathi Rao et al., 2012; Pandey et al., 2017c), and Gondwana coalfield (Srivastava et al., 2009; Chalapathi Rao et al., 2014). characters of subduction-related mafic magmas (Pandey et al., 2017a, 2018b). Crustal materials are characterized by elevated $\mathrm{U}$ and $\mathrm{Pb}$ content, hence, trace element ratios such as $\mathrm{Nb} / \mathrm{U}$ and $\mathrm{Ce} / \mathrm{Pb}$ are considered as important indicators of crustal contamination. A reducing value of $\mathrm{Nb} / \mathrm{U}$ and $\mathrm{Ce} / \mathrm{Pb}$ of the mantle zones suggest them to be metasomatized by the subduction-related fluids. The clear cut evidence of subduction is again exhibited on the suppressed $\mathrm{Nb} / \mathrm{U}$ and $\mathrm{Ce} / \mathrm{Pb}$, and elevated $\mathrm{Th} / \mathrm{Yb}$ ratios in these calc-alkaline lamprophyres (Fig. 7, 8). Pandey et al. (2017a, 2018b) have suggested the presence of a subduction modified mantle wedge in the SCLM beneath EDC, probably, as a result of Neoarchean accretion related

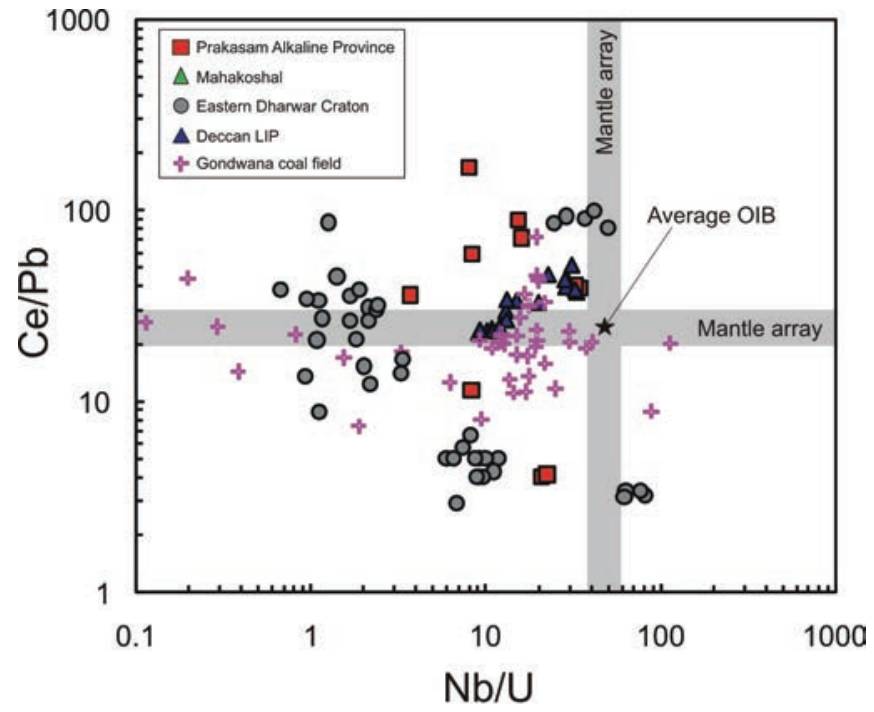

Figure 7. $\mathrm{Nb} / \mathrm{U}$ vs. $\mathrm{Ce} / \mathrm{Pb}$ variation plot with mantle array defined by MORBs and OIBs from Hofmann et al. (1986) and average OIB data from Sun and McDonough (1989). Data sources are same as in Fig. 6.

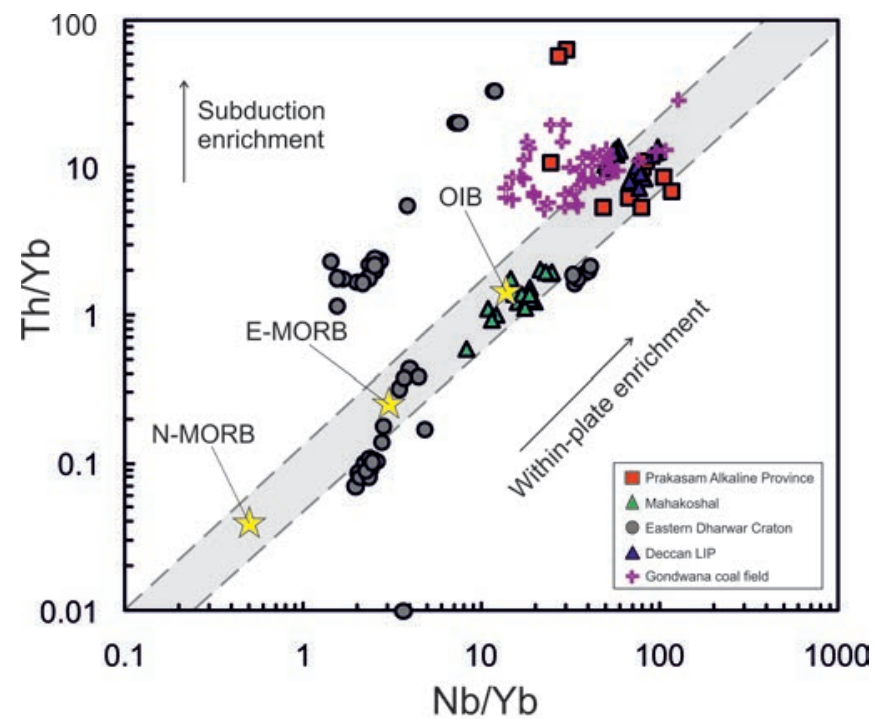

Figure 8. $\mathrm{Nb} / \mathrm{Yb}$ vs. $\mathrm{Th} / \mathrm{Yb}$ trace element ratio diagram (after Pearce, 2008) showing mantle array defined by MORBs and OIBs. Lamprophyres from the Mahakoshal belt show affinity to the OIBs and within-plate enriched mantle source is represented by the lamprophyres from the Prakasam Alkaline Province, the Deccan LIP and the Gondwana coalfield. Data sources are same as in Fig.6. 
growth of the Dharwar Craton (Jayananda et al., 2018 and references therein).

Chemically distinct from these rocks are the shoshonitic lamprophyres exposed at Udiripikonda, Sivarampeta and Korakkodu in the Wajrakarur kimberlite field of the EDC. These rocks host olivine and oscillatory zoned pyroxene phenocrysts silica-undersaturated (Pandey et al., 2017b; Khan et al., 2018). These pyroxenes show variable Ti content leading to their transitional or mixed orogenicanorogenic geochemical behaviour, which is also reflected by their bulk-rock geochemistry, alike the lamprophyres from Prakasam Alkaline Province (Fig. 3). An interesting finding is the presence of sagenitic texture in mica grains as a result of exsolution of 5-10 $\mu \mathrm{m}$ titanite needles, which is found in shoshonitic lamprophyres from other parts of the globe as well (Raghuvanshi et al., 2019). The elevated $\mathrm{K}_{2} \mathrm{O}$ content as compared to other lamprophyres from the EDC is due to the abundance of biotite. In the $\mathrm{SiO}_{2}$ vs. $\mathrm{MgO}$ and $\mathrm{Al}_{2} \mathrm{O}_{3}$ vs. $\mathrm{TiO}_{2}$ variation plots (not shown), these rocks show a mixed affinity to the global alkaline and calc-alkaline lamprophyres. The SIMS zircon U-Pb isotopic data gave an emplacement age $2511 \pm 6.6$ Ma for the samples from the Udiripikonda lamprophyre, which has been interpreted to be due to crustal derivation of zircons in lamprophyre dyke as the host granites in EDC have an age of 2.51 Ga (Khan et al., 2018). Pandey et al. (2017b) have suggested that this dyke, emplaced in the vicinity of 1100 Ma kimberlites without any cross-cutting relationship between two, and therefore should be coeval, which is also further apparent from whole-rock Rb-Sr isochron age of $0.96 \mathrm{Ga}$. Certain trace element ratios such as $\mathrm{Th} / \mathrm{Yb}, \mathrm{Nb} / \mathrm{Yb}$, $\mathrm{Mo} / \mathrm{Pr}, \mathrm{Ce} / \mathrm{Pb}$ and $\mathrm{Nb} / \mathrm{U}$ along with abundant $\mathrm{TiO}_{2}$ content in these shoshonitic lamprophyres from Wajrakarur kimberlite field show their affinity to the ocean island basalts (OIBs) (Fig. 7, 8); however, the radiogenic initial ${ }^{87} \mathrm{Sr} /{ }^{86} \mathrm{Sr}$ ratios along with un-radiogenic initial $\varepsilon \mathrm{Nd}$ highlight the role of an old (Neoarchean ( 2.6 Ga) Nd model ages) enriched sub-continental lithospheric mantle (SCLM) in their genesis, unlike the OIBs, which are essentially derived from an asthenospheric mantle (Fig. 9). This character has been explained to be a result of metasomatism of the lower reaches of SCLM by the metasomatic fluids percolating from the sub-lithospheric depths (Pandey et al., 2017b; Khan et al., 2018). Based on the elevated Zr/Hf ratios and

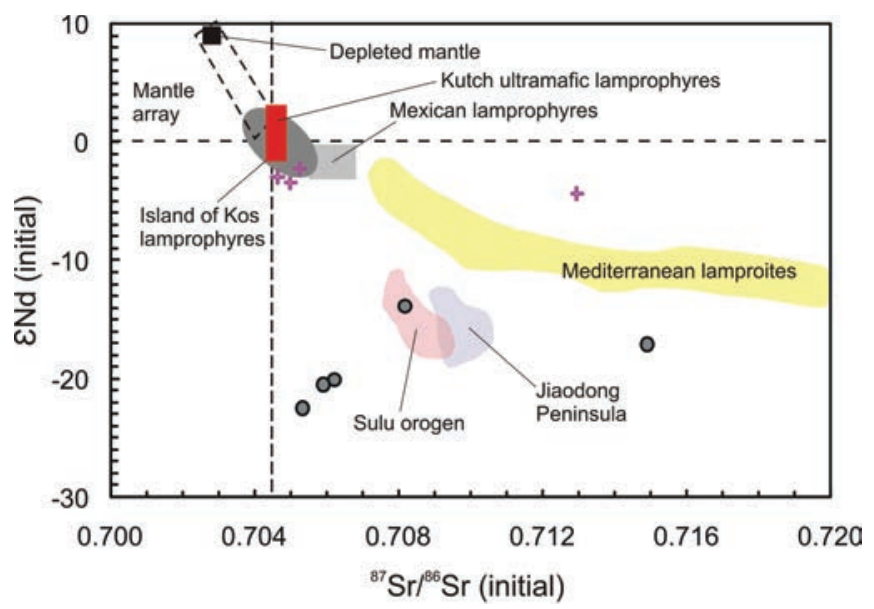

Figure 9. ${ }^{87} \mathrm{Sr} /{ }^{86} \mathrm{Sr}_{\text {initial }}$ vs. $\varepsilon N d_{\text {initial }}$ variation in the lamprophyres from the Eastern Dharwar Craton (solid circles) and Gondwana coalfield (cross) showing their derivation from an old subcontinental lithospheric mantle and an enriched mantle related to mantle plume, respectively. silica under-saturated nature of these rocks, Raghuvanshi et al. (2019) have proposed carbonatite metasomatism overprint on the SCLM, which had already gone a previous episode of subduction-related metasomatism, probably, during Neoarchean accretion related-growth of the EDC as reflected by their Neoarchean depleted mantle Nd model ages. A previous silicate related metasomatic activity is not only apparent from the enriched isotopic character, but also from moderate $\mathrm{Nb} / \mathrm{La}$ and elevated Ba/Th ratios. Giri et al. (2019) have identified three different domains of lamprophyres in the EDC based on contribution of different mantle reservoir sources: Domain I - which includes SCLM (sub-continental lithospheric mantle) source metasomatized by subduction components (Kadiri lamprophyre); Domain II, which includes a mixed source with involvement of both SCLM and asthenosphere (Udiripikonda and Korakkodu lamprophyre); and Domain III that includes plume originated lamprophyres (Ankiraopalli lamprophyre).

\section{Central Indian lamprophyres}

The lamprophyres in Central India are exposed mainly in the Jungel valley, the Chitrangi region, and the Sidhi region of Mahakoshal supracrustal belt (MSB), which is a part of Central India Tectonic Zone (CITZ) (Fig. 1). CITZ which is one of the ENE-WSW trending major crustal features in the peninsular India fenced by SonNarmada North Fault (SNNF) and Son-Narmada South Fault (SNSF) in the north and south, respectively (see Roy and Bandyopadhyay, 1988). The ENE-WSW trending MSB extend for $500 \mathrm{~km}$ and comprises granitic plugs, syenites, alkaline intrusive along with pyroclastic metavolcanics and chemical precipitates, which reflects a greenstone association of typical rift setting (Srivastava, 2013; Srivastava and Chalapathi Rao, 2007). Granite-granodiorite, syenites, dolerites and gold-bearing quartz-carbonate veins constitute the youngest lithologies of the supracrustal belt, whereas lamprophyres here constitute youngest magmatic event and yielded an age of 1610 Ma (Nair et al., 1995). These lamprophyres show sharp contacts with the supracrustals and were emplaced prior to regional deformation in MSB.

The Jungel valley Paleoproterozoic lamprophyres intrude the MSB, located $280 \mathrm{~km}$ east of the Mesoproterozoic diamondiferous Majhgawan pipe, and are exposed as dykes, plugs and lava flows. These lamprophyres show inequigranular, porphyritic and glomeroporphyritic texture, where original mineralogy of the phenocrysts of olivine, pyroxene, mica and amphibole (10-20\% by volume) is completely altered and only their relicts are present (Srivastava and Chalapathi Rao, 2007). Large panidiomorphic phenocrysts are suggestive of crystallization from a water-rich magma, whereas multiple generations of phenocrysts (olivine, clinopyroxenes, mica and amphibole) suggest repeated degassing and recharge of magma (Currie and Willliams, 1993). Alumina vs. Mg\# plot suggests that they contain phlogopite as the dominant mica (Fig. 4). Mineral chemistry studies by Vinod Kumar (1995) reveal that three types of amphiboles are present viz., hornblende, oxy-hornblende (lampropbolite) along with the rare presence of alkali-amphibole (kaersutite and kataphorite), which suggest alkaline nature of lamprophyric rocks (see Rock, 1991). Feldspar constitute 0.35$23.75 \%$ of the groundmass ( $>90 \%$ of the rock) of the Jungle valley lamprophyres, in which plagioclase is dominant than orthoclase. A notable feature of the feldspars is their partially altered and rugged boundaries, which represent evidence of metamorphic 
recrystallization. Few lamprophyres show the presence of rounded or elliptical ocelli (up to $5 \mathrm{~mm}$ size). They are mostly undersaturated, ultrabasic, and sodic in nature $\left(\mathrm{Na}_{2} \mathrm{O}>\mathrm{K}_{2} \mathrm{O}\right)$, with only a few of them which are potassic (see Srivastava and Chalapathi Rao op. cit; Fig. $6 A)$. They are mainly alkaline with some plugs of calc-alkaline nature (Fig. 6B). On the basis of petrography and bulk-rock geochemistry, these rocks have been classified as alkaline lamprophyre in general and camptonites in particular. In the primitive-mantle normalized multi-element diagram, (i) all elements show an enrichment over the primordial mantle, (ii) trends of all HFSE are similar and (iii) but LILE show a wide variation. Enrichment in LREE over HREE which suggest a strong fractionation and resemble those of mildly undersaturated alkaline basalt; whereas parallel chondrite normalized REE patterns imply derivation from a similar mantle source. Fractional crystallization has a strong influence on their magma evolution. The Jungel lamprophyres have been interpreted to exhibit primitive as well as evolved nature of magma. A high concentration of LREE and relatively high concentration of compatible elements \{ Ni (up to 729 ppm) and Cr (up to 1280 ppm)\} suggest that magma was produced by a small degree of partial melting of peridotite in garnet stability and derived from shallower depths than the diamondiferous Majhgawan pipe (Srivastava and Chalapathi Rao, 2007).

The Chitrangi lamprophyres intrude MSB and are situated in the eastern part of the MSB, exposed as dykes and plugs and are found to be associated with the carbonatites. These lamprophyres are melanocratic and constitute of pseudomorphs of olivine replaced by calcite, amphibole, mica and pyroxenes. A noteworthy feature of these lamprophyres is the presence of melanite garnet and rounded to elliptical carbonate ocelli (Srivastava, 2013). On the basis of petrography and bulk-rock geochemistry, these rocks have been classified as ultramafic lamprophyres in general and aillikites in particular. High Mg\#, Ni and Cr content along with low HREE concentration corroborate their primary nature. The Chitrangi lamprophyres are found associated with the carbonatites, but exclude any genetic relationship with the latter. Rubidium, $\mathrm{Ba}, \mathrm{K}$ and $\mathrm{Sr}$ of the Chitrangi lamprophyres display a wide range of variation and thus reflects subtle post-magmatic alteration. Both the Jungel valley and Chitrangi lamprophyres have ocelli present in them thereby suggesting the role of late-stage liquid immiscibility. Trace element ratios $\mathrm{Th} / \mathrm{Yb}$ vs Nb/Yb of the Jungel and Chitrangi lamprophyre shows similarity with the mantle array and within plate characteristics (Fig. 8). It has been inferred that the Chitrangi lamprophyres were emplaced during the early stages of rifting in MSB due to lithospheric relaxation caused, very likely, by mantle plume activity (Srivastava, 2013).

The Sidhi Gneissic complex (SGC) is a 2.5 Ga old tectonic block, which is situated at the northern margin of the CITZ. The SGC is an inlier of granite-gneiss-migmatite, surrounded by MSB in the north and by the Vindhyan basin in the south (Roy and Bandhyopadhyaya, 1988). A number of lamprophyres, lamproite and ultramafic dykes have been reported from the Sidhi region (see Bhattacharya et al., 2014; Satyanarayanan et al., 2017, Giri et al., 2018 and references therein). Previously, Paul and Potts (1981) and Paul and Sarkar (1984) reported lamprophyres with mica as dominant phenocryst along with olivine and classified them as olivine-minette. Giri et al. (2018) reported the occurrence of a lamprophyre from south-west of Banjari area near Sidhi town. This NW-SE trending lamprophyric dyke occurs as small body and intrudes the Sidhi alkaline complex. This lamprophyre is meso-melanocratic and constitutes mica- dominated phenocrysts and a groundmass comprise feldspar, titano-magnetite, apatite, secondary carbonates and opaques (pyrite and chalcopyrite). A notable feature of this lamprophyre is the occurrence of cobaltoan pyrite, which contains an appreciable amount of cobalt up to (5.61 wt\%) and minor content of nickel (up to $0.70 \mathrm{wt} \%$ ).

\section{Gondwana coalfield lamprophyres}

The Eastern Indian shield comprises the Singhbhum craton, Singhbhum mobile belt, Chotanagpur gneissic terrain (CGT) and the Shillong plateau. Gondawana coalfield such as the Bokaro, the Daltonganj, the Jharia and the Karanpura are situated in the eastwest trending Damodar valley located in the CGT at the northernmost margin of Singhbhum craton. Interestingly, Damodar valley is the only known geological domain in the Indian shield which host both Early Cretaceous (Rajmahal Traps) and Late Cretaceous (Deccan Traps) volcanic igneous activity. Hundreds of lamprophyres intrude the coalfield and often burn the coal leading to ash locally known as Jhama. Kent et al. (1998) reported Ar-Ar age of 117 Ma for some of these dykes which are almost synchronous with the nearby Rajmahal basalts and linked them to the Kerguelen mantle plume. The Gondwana lamprophyres have been variably described by various workers viz., kimberlites (Kent et al., 1998; Kumar et al., 2003); lamprophyres sensu stricto (Paul and Potts, 1981, Rock et al., 1992), as well as lamproites (Jia et al., 2003).

The Gondwana lamprophyres from the Jharia and Raniganj coalfields are shown to have petrological and geochemical similarity to cratonic magmas (kimberlites and lamproites) as well as rift-related magmas (aillikites) (Srivastava et al., 2009; Chalapathi Rao et al., 2014). Petrographic study reveals they constitute of phenocrysts of pseudomorphs of olivine, amphibole and mica along with groundmass of feldspar, primary carbonates and opaque minerals. Mineral chemistry studies reveal mica to be mainly phlogopite (Fig. 4) and exhibits a wide variation in its composition in terms of $\mathrm{TiO}_{2}, \mathrm{Al}_{2} \mathrm{O}_{3}$ and $\mathrm{FeO}_{\mathrm{T}}$ contents. On the other hand, the amphiboles are primary as well as the secondary type (Fig. 5). High modal abundances of the mica, apatite, and carbonate reflect high-volatile content of their parent magma. Major rock geochemistry suggests them to be silicaundersaturated, ultrapotassic and ultramafic (Fig. 6A and B). Transition elemental abundances are variable with a high Mg\# (59.1571.56), Ni (20-690 ppm), and Cr (220-1200 ppm) and a positive correlation between LILE and HFSE represents their uncontaminated and primary nature. Cerium and Nb contents are many folds higher than that of MORB or OIB, even continental lithospheric mantle and nullify their direct derivation from the asthenosphere. Incompatible element ratios viz., $\mathrm{Ce} / \mathrm{Pb}, \mathrm{Nb} / \mathrm{U}, \mathrm{Th} / \mathrm{Yb}$, and $\mathrm{Nb} / \mathrm{Yb}$ reveal their similarity with characteristics in between OIB and pelagic sediments and support the idea of the presence of an ancient subduction component in their source (Fig. 7 and 8). Depletion in sodium, silica and alumina along with enrichment in $\mathrm{K}, \mathrm{Ti}$, and $\mathrm{P}$ typically are similar to the aillikites (Rock, 1991; Tappe et al., 2006). The ${ }^{87} \mathrm{Sr} /{ }^{86} \mathrm{Sr}$ ranging between 0.704637 and 0.712919 and $\varepsilon N d$ varying between -2.3 and 4.4 relate them with the Island of Kos and Mexican lamprophyres (Fig. 9). Chalapathi Rao et al. (2014) suggested them to have been derived from mantle source which had undergone long term enrichment of incompatible trace elements and indistinguishable from that of Kerguelen mantle plume-derived basalts. Their $\mathrm{T}_{\mathrm{DM}}$ (depleted mantle) model age ranges from 0.95-1.4 Ga and correlates well with that of Deccan age orangeites from the Bastar craton and with the 1.1 Ga emplacement ages of kimberlites from the Eastern Dharwar Craton, 
southern India. The Gondwana lamprophyres are interpreted to be generated by a small degree of partial melting of depleted harzburgite which subsequently metasomatised by carbonate-rich fluids at lithospheric depth within garnet stability field and that the Kerguelen plume provided the heat source (Chalapathi Rao et al., 2014).

\section{Lamprophyres of the NE India}

Even though lamprophyres are reported from the NE India viz., Meghalaya plateau (Table 1) only petrographic studies were undertaken and detailed petrogenetic studies are lacking. Nongchram Fault Zone lamprophyres are comagmatic and genetically linked with nearby carbonatite (Nambiar, 2007). These lamprophyres host country rock fragments, as well as mantle derived ultramafic nodules, aggregated megacrysts and lapilli like structures. Conspicuous presence of ocelli has also been discussed as a characteristic feature of these lamprophyres. Ocelli are commonly zoned, with carbonaterich (rarely analcime) inner zone and an outer zone rich in alkali felspars, mica, pyroxenes and opaque minerals. Srivastava et al. (2016) from their study of early Cretaceous, potassic lamprophyres from Garo hills evinced that lamprophyres are product of mantle heterogeneity at rather than any input of mantle plume magmatism.

\section{Deccan Large Igneous Province lamprophyres}

The fact that alkaline magmatism is temporally associated with the continental flood basalt in a LIP is now well established (Rock, 1977; Queen et al., 1996; Leat et al., 2000; Riley et al., 2003; Tappe et al., 2006). Numerous lamprophyres, either in form of dykes and plugs are associated with the Deccan flood basalts (Subba Rao, 1972; Bose, 1980; Gwalani et al., 1993). These lamprophyres occur along the various rift zones such as E-W trending Narmada rift, Cambay rift and western coastal rifted margin (e.g., Melluso et al., 2002; Dessai and Viegas, 2010; Chalapathi Rao and Lehmann, 2011; Pandey et al., 2019). Most of them post-dates the Deccan Traps and their precise emplacement ages are scanty (see Table 1).

Camptonite and monchiquite (varieties of alkaline lamprophyre) and kersantite (a type of calc-alkaline lamprophyre) associated with the alkaline complexes and with the basalts of western and northwestern portions of Deccan LIP are reported from: (i) the Phenaimata alkaline complex (Durgadamath, 1984); (ii) the Girnar alkaline complex (Subba Rao et al., 1971; Paul et al., 1977), (iii) the Kutchh (Jaitly et al., 1980), (iv) the Kanwad-Panwad region and exposed along Heron River sections (Sukeshwala and Avasia, 1972), (v) the Chhaktalo and Bhakhatgarh-Phulmal, Chhotaudepur areas (Chawade, 1996; Hari, 1998; Hari et al., 2000; Randive et al., 2005, Chalapathi Rao et al., 2012), and (vi) Murud Janjira area (Deshpande and Chakranarayan, 1973; Dessai et al., 1990; Dessai and Viegas, 2010). The Deccan LIP hosts the highest number of lamprophyre dykes all over the Indian shield, which is well illustrated in Fig. 1. The lamprophyre occurrences in the Deccan LIP and NW part of India can be further sub-divided into: (i) lamprophyres from the Chhotaudepur alkaline sub-province and (ii) lamprophyres from the Kutch rift zone.

The Chhotaudepur alkaline sub-province, which lies within the E-W trending Narmada rift valley, has several discrete occurrences of lamprophyre bodies exposed at Chhotaudepur, Dongargaon,
Hamirpur, Heran River, Jitnagar, Kanthari, Moradungari, Panwad, Pipliwat and Seraphalia (see Table 1). The Kutch rift zone has exposures of Mid-Cretaceous ultramafic lamprophyre at Palanpur (Karmalkar et al., 2014; Pandey et al., 2018a). Detailed mineralogical and geochemical study has not yet been published on the lamprophyres from the Phenaimata, Mundwara, Girnar complexes and the Heron river sections. However, the lamprophyres from the Chhaktalao, the Chotaudepur, the Murud Janjira and the Kutch have been given due attention, which is discussed below.

The lamprophyres from Chhakatlao area in the Deccan Traps contain abundant pyroxene and olivine as phenocrysts that show conspicuous zoning, and have been classified as kersantite (alkali lamprophyre) and camptonite (calc-alkaline lamprophyre) as the plagioclase dominated potassic feldspar in the groundmass (Hari, 1998). This is corroborated by the bulk-rock geochemistry of these lamprophyres, which has been used to understand the associations of these lamprophyres with the Deccan volcanics as well as the carbonatites. On the basis of the presence of clinopyroxene blebs in these lamprophyres and the matrix of the carbonatites, Hari (1998) concluded that a silicate-carbonate liquid immiscibility model explains the genetic link between the two. This relation has further been established by the melt inclusions study on these olivine and clinopyroxene phenocrysts by Hari et al. (2000). These authors have shown that the mafic phenocrysts trapped bubble inclusions of $\mathrm{CO}_{2}$ at a depth of $10-15 \mathrm{~km}$ at 4.6 and $3.7 \mathrm{kbar}$ pressure in olivine and pyroxene, respectively. The temperature of these $\mathrm{CO}_{2}$ melt inclusions have been found to be $1215-1245^{\circ}$ and $850-1150^{\circ} \mathrm{C}$ for the olivine and pyroxene respectively, Based on these estimated thermobarometric conclusions, Hari et al. (2000) have proposed that these lamprophyres originated from the shallow mantle depths, probably, the spinel lherzolite field. Chalapathi Rao et al. (2012) have presented the mineralogy and geochemistry of the Chhotaudepur lamprophyres, which are some of the longest known lamprophyre dykes in India, in detail. Although, present in the Deccan LIP, which is considered to be a manifestation of mantle plume activity, the clinopyroxenes of the Chhotaudepur lamprophyres show affinity to the orogenic alkaline magmas due to their depletion in Ti content (Fig. 3). The mica is classified as biotite and is very high in alumina content showing affinity to the alkaline as well as calc-alkaline lamprophyres (Fig. 4). As mentioned earlier, the mixed geochemical affinity is shown by the shoshonitic lamprophyres, which have a very high content of total alkalis. Such characters are also well exhibited from the bulk rock geochemistry of these lamprophyres (Fig. 6; Chalapathi Rao et al., 2012). The trace element ratios such as $\mathrm{Nb} / \mathrm{U}, \mathrm{Ce} / \mathrm{Pb}, \mathrm{Th} / \mathrm{Yb}$ and $\mathrm{Nb} /$ $\mathrm{Yb}$ in these lamprophyres highlight the involvement of OIB-type enriched mantle in their genesis, which is also exhibited for other Deccan lamprophyres (Fig. 7 and 8).

A chrome diopside megacryst has been recently recovered from the Late Cretaceous Mundwara lamprophyre (Sharma et al., 2018). Single pyroxene thermobarometry revealed that it was derived from a depth range of $\sim 100 \mathrm{~km}$, which is relatively much deeper than that of the chrome-diopside megacrysts ( $\sim 40-50 \mathrm{~km})$ reported in spinellherzolite xenoliths from the alkali basalts of Deccan age (ca. 66- 67 Ma) from the Kutch, NW India. These results highlight that the preDeccan lithosphere beneath the Mundwara complex was at least $\sim 100$ $\mathrm{km}$ thick and similar in composition to that of the cratonic lithosphere (Sharma et al., 2018). A mantle-derived ultramafic xenolith entrained the Eocene (ca. $55 \mathrm{Ma}$ ) lamprophyre dyke from the Dongargaon is found to have an overlapping composition with that reported from 
worldwide mantle peridotite xenoliths Pandey et al., 2017c). Presence of phlogopite and apatite as phases in the xenolith provided the first direct petrographical evidence for the modal metasomatism in the post-Deccan subcontinental lithospheric mantle (SCLM) from this domain. Preservation of phlogopite and apatite in the ultramafic xenolith imply that some of the readily fusible metasomatized portions in this domain escaped wholesale melting during the eruption of the Deccan Traps, possibly due to the variable thickness of the underlying SCLM (Pandey et al., 2017c). Lamprophyre xenoliths, of an earlier episode, have been reported from the Dongargaon lamprophyre highlighting its polychromous nature very likely due to extensional events related to the reactivation of the Narmada rift zone (Pandey et al., 2018c).

The lamprophyres exposed at the Murud Janjira constitute a part of the wide spectrum of alkaline rocks including melanephelinites, nephelinites, tephrites and nepheline syenites at the Mumbai coastal area (Melluso et al., 2002). Interestingly, the lamprophyres stand distinct from the rest of the associated alkaline rocks in terms of their geochemistry and display very high concentrations of $\mathrm{Nb}, \mathrm{La}, \mathrm{Ce}$, Nd, Zr and Ti. Melluso et al. (2002) have published Nd isotopic data for only one and Sr isotope data for two samples (not shown here). Considering an emplacement age of $65 \mathrm{Ma}$, the initial ${ }^{87} \mathrm{Sr} /{ }^{86} \mathrm{Sr}$ ratio varies between 0.70415 and 0.70420 , with an initial $\varepsilon N d$ of +4.4 , which falls within the mantle array showing affinity to the OIBs in general and Reunion hotspot in particular. Based on their trace element modelling results, these authors have proposed a wide range of degree of melting took place in the genesis of these alkaline rocks with lamprophyres generated at the lowest proportions of partial melting. This wide range in degree of melting of heterogeneous, volatile-rich $\left(\mathrm{CO}_{2}+\mathrm{H}_{2} \mathrm{O}+\mathrm{F}\right)$ lithospheric mantle explains the drastic compositional difference between the lamprophyres and other alkaline rocks at Murud Janjira. However, from their high initial $\varepsilon N d(+4.4)$ suggest that they tap an isotopically depleted sub-lithospheric (asthenospheric) mantle. Xenoliths recovered from the Murud Janjira lamprophyres (west coast of India) reveal that granulites and pyroxenites are the dominant rock types in the underlying lithosphere and that lower crust here is more mafic in composition (Dessai et al., 2004).

The lamprophyre exposed in the Kutch area has been dated to be Mid-Cretaceous (U-Pb perovskite age of $124 \pm 4 \mathrm{Ma}$ ) by Karmalkar et al. (2014), which intrudes the Katrol Formation of upper Jurassic to Early Cretaceous age. This dyke was originally identified by Karmalkar et al. (2014) as a lamproite that originated from a mantle showing signatures of mixing between enriched and depleted domains. The authors suggested the lamproite to represent an earlier igneous event related to the rifting unlike the alkaline magmatism related to the Deccan volcanism that dominated the region. Detailed mineralogical and geochemical investigations were subsequently carried out by Pandey et al. (2018a) on this anorogenic dyke, and it has been re-classified to be a damtjernite (ultramafic lamprophyre). This silica-undersaturated potassic and primitive lamprophyre contains phenocrysts of olivine, phlogopite, and clinopyroxene in a groundmass of perovskite, nepheline and magnetite. High Mg\# and low alumina content in the phlogopites of these rocks contrary to other Deccan lamprophyres show their affinity to the global ultramafic lamprophyres (Fig. 4). Pandey et al. (2018a) have shown that the geochemical characters of these Mid-Cretaceous (124 Ma) dykes are strikingly similar to the End-Cretaceous (69 Ma) ultramafic lamprophyres exposed as dykes and sills at the Tethyan Indus Suture Zone. Trace element ratios such as $\mathrm{Ce} / \mathrm{Pb}, \mathrm{Nb} / \mathrm{U}, \mathrm{Th} / \mathrm{Yb}, \mathrm{Nb} / \mathrm{Yb}, \mathrm{Nb} / \mathrm{La}$ attest to the OIB-type affinity of these rocks (Fig. 7, 8; Pandey et al., 2018a), which is further corroborated by the isotopic ratios i.e. ${ }^{87} \mathrm{Sr} /{ }^{86} \mathrm{Sr}$ ranging between 0.70460 and 0.70461 and $\varepsilon N d$ varying between +2.56 and -0.69 (Fig. 9). Based on high $\mathrm{Rb} / \mathrm{Sr}$, Nb and lower $\mathrm{La} / \mathrm{Sm}$ a carbonatitic metasomatic melt responsible for precipitating metasomatic phlogopite-rich veins in the lithospheric mantle have been proposed as the source region for these rocks. Although, the dyke shares a temporal relation to the Kerguelen plume derived Rajmahal-Sylhet Traps and associated alkaline rocks from eastern India, it is spatially compatible with the Reunion plume derived Deccan Traps. This conundrum has been explained by Pandey et al. (2018a) by three models- (i) either it represents the earliest magmatic episode of the Reunion plume, (ii) it represents product of prolonged multiple rifting episodes in the Kutch domain as a result of far-field plate reorganization, or (iii) it represents an alkaline magmatic episode between the eruption of Rajmahal-Sylhet and Deccan volcanics. Nonetheless, the trigger for the Kutch ultramafic lamprophyre magmatism remains an open question.

Recently, Pandey et al. (2019) inferred the carbonate metasomatism of the post-Deccan SCLM in NW India, based on their study on the geochemistry of the lamprophyre dykes (sannaite and camptonite) from the Chhotaudepur alkaline province from the Narmada rift zone. These dykes are found to be intruding the Deccan basalts and therefore, provide unique opportunity to study the effects of the mantle plume on the SCLM beneath NW India.

\section{Indian lamprophyres and their relationship with the kimberlite clan rocks (KCRs)}

The volatile-rich, low-volume, ultramafic to mafic alkaline rocks such as kimberlites (Group I archetypal type), orangeites (previously termed as Group II or micaceous kimberlites) and lamproites, together with lamprophyres, tap the deep complex mantle domains and are carriers of the "mantle cargo" which includes a plethora of xenoliths and xenocrysts (including the diamond). Dawson (1987) used the term 'kimberlite clan' for the first time because of complex mineralogy and large variation in chemistry of the kimberlites and related rocks such as lamproites and lamprophyres. Likewise, Rock (1991) proposed a 'lamprophyre clan' and included kimberlites as well as lamprophyres sensu stricto in it. Haggerty and Birkett (2004) used kimberlite clan rocks (KCR) for some kimberlitic rocks from the Dharwar Craton as they share similarities in terms of their volatile content, mineralogy, and geochemistry and macroscopic appearance as well. The problem of identifying them as per the existing petrogenetic classification by IUGS has generated much ambiguity resulting in assigning different names without any strong affinity to a particular clan.

Amongst the KCRs, the orangeites akin more to lamproite group of rocks. Of the different varieties of lamprophyres, the ultramafic lamprophyres (UML) are grouped with kimberlites, whereas the alkaline and calc-alkaline lamprophyres are considered quite distinct and different from kimberlites. The predominance of feldspar, plagioclase, and hydrous phases (such as amphibole, and biotite) in alkaline and calc-alkaline lamprophyres and their association within the intra-plate and subduction/or post-collision related tectonic setting respectively discriminate them from the kimberlites. Out of three endmembers of the UML (alnöites, aillikites and damtjernites) the aillikites share more similarities with kimberlites whereas alnöites 
and damtjernites can be readily discriminated by the presence of essential groundmass melilite and nepheline, respectively (Tappe et al., 2005). Following these criteria, various West Greenland alkaline dykes, which were initially regarded as kimberlites, have been reclassified subsequently as ultramafic lamprophyres and more specifically as aillikites (Tappe et al., 2005). Kimberlites and UML despite having similarities such as silica under-saturated nature, presence of macrocrystic and phenocrystic olivine and phlogopite, still differ in their tectonic setting. Kimberlites are restricted to within the intra-cratonic settings wherein they tap the deep lithospheric mantle whereas UML are intrinsically associated with a rifted cratonic lithosphere (Tappe et al., 2009). However, based on the presence of Ti-rich phlogopite, high $\mathrm{Na} / \mathrm{K}$ amphibole, and Ti-rich schorlomite garnet, Dongre et al. (2019) have identified pipe-8 of the Wajrakarur kimberlite field to be an ultramafic lamprophyre (aillikites). Much of the on-going debate hinges on the genetic link between kimberlites and ultramafic lamprophyres, and contributions from the lithospheric and/or sub-lithospheric mantle (Foley et al., 2009; Francis and Patterson, 2010; Mitchell and Tappe, 2010) as both these rock types contain significant carbonate component within their source regions.

From the Indian front, there is still a paradox regarding the nomenclature of volatile-rich ultramafic intrusions in the EDC as kimberlite, lamproite or UML as they tend to display a transitional nature. One of the best examples is the Khaderpet plug from the Wajrakarur kimberlite field of the EDC, which is associated with the carbonatite intrusions (Smith et al., 2013). Following the mineralogical genetic classification, presence of Ti-andradite and significant amounts of carbonate content necessitates us to classify the Khaderpet KCR as ultramafic lamprophyre. However, high $\mathrm{CaO}$ and enrichment in LREE together with the low whole-rock MgO content suggest the Khaderpet KCR be transitional between kimberlite and ultramafic lamprophyre (Smith et al., 2013). The Arkhangelsk Alkaline Igneous Province (Russia) also has a similar association of kimberlite, olivine lamproite, melilite-bearing alkaline picrite and carbonatite showing transitional affinities to kimberlite and ultramafic lamprophyres (Mahotkin et al., 2000). Likewise, the presence of Ti, Al, Ba-rich phlogopites, Na-enriched amphibole, and Ti-rich schorlomite garnet together with the slightly elevated ${ }^{87} \mathrm{Sr} /{ }^{86} \mathrm{Sr}$ initial values in pipe-8 of the Wajrakarur kimberlite field has led Dongre et al. (2019) to reclassify it as ultramafic lamprophyre (aillikite). Interestingly, Scott Smith (1989) also noted the probable presence of melilite from Pipes2 and 5 of the Wajarakarur kimberlite field, EDC, which could give them a status of UML which needs to be corroborated through detailed mineralogical characterisation. The melilite reported by Scott Smith (1989) has compositions similar to those of hydrogrossular, which is a secondary mineral in some of the WKF intrusions (Kaur and Mitchell, 2016). According to Kaur and Mitchell (2016), the lath shaped mineral inferred to be melilite by Scott Smith (1989) is actually hydrogrossular, which is a pseudomorph after a lath shaped parent mineral (cymrite). The Palanpur damtjernite from the Kutch rift zones of NW India is the only archetypal UML to our knowledge which is neither associated with KCRs nor display any transitional nature (Pandey et al., 2018a).

As stated before, kimberlites share many mineralogical similarities with the olivine lamproites which can be of overlapping nature. In this context, Indian kimberlites serve as the best representatives since many of them from Wajrakarur, and Narayanpet kimberlite fields from the EDC and diamondiferous Majhgawan pipe of central India are neither archetypal kimberlites nor lamproites (e.g., Haggerty and
Birkett, 2004; Chalapathi Rao et al., 2005; Chalapathi Rao et al., 2012; Smith et al., 2013). Likewise, Reddy (1987) classified the ultramafic intrusions of the Wajrakarur kimberlite field to be lamproites considering the probable presence of leucite and sanidine. However, Chalapathi Rao et al. (2004) described them to be phlogopite-rich, monticellite bearing archetypal hypabyssal kimberlites on the account of their mineralogy geochemistry and isotopic parameters. Based on the spinel mineral composition and occurrence of barian lamprophyllite, Fareeduddin and Mitchell (2012) attached a lamproite status to some of these rocks. Presently, there is no strict consensus regarding their classification yet we can demonstrate that these rocks differ from each other if we use the mineralogical, geochemical and isotopic characters in unison instead of naming them solely on the basis of existing mineral-genetic classification schemes. For instance, Shaik et al. (2018) detected various populations of olivine, phlogopite and clinopyroxene from Pipe-4, WKF and referred it to be a lamproite, and attributed its genesis to the abundance of MARID-type metasomatic veins within the source wall-rock region. If that is so, this pipe should either display the isotopic characters (in Sr-Nd space) of MARID-type of 'enriched' source regions or define a mixing array between an enriched (EM-II like) and an isotopically depleted geochemical reservoir (Fitzpayne et al., 2019) which needs to be confirmed by future studies. Furthermore, it should be highlighted that the phlogopite and groundmass spinel from WKF and NKF follow the compositional trends transitional between kimberlite and orangeites (Chalapathi Rao et al., 2012). On the basis of mineral chemistry, Chalapathi Rao et al. (2012) demonstrated they should be classified as transitional varieties but if we consider their geochemical and isotopic characters they can be classified as kimberlites as well. As the compositional trends are essentially the functions of phases that are generated during the crystallisation interval, which in turn, depend upon a variety of aspects such as the magma composition, pressure, temperature and extent of late-stage magmatic oxidation they do not necessarily constitute the intrinsic parameters of the rocks. This is further attested from the evidence that the mineral compositions from the newly discovered late-stage kimberlite dykes from the Premier diatreme root of Kaapvaal craton display a marked a deviation from the trends that are hitherto devised to be robust for the archetypal kimberlites (Dongre and Tappe, 2019). Two decades ago, Taylor and Kingdom (1999) questioned the robustness of existing mineralogical-genetic schemes by pointing out that the Jagesfontein kimberlite of southern Africa has petrographic and mineralogical aspects common to both kimberlite and orangeite but still isotopically it displays an archetypal kimberlite character.

It is important to highlight those recently re-classified lamproites from the EDC (Kaur and Mitchell, 2013, 2016; Kaur et al., 2013; Shaikh et al., 2017, 2018), which were initially considered to be kimberlites, are neither ultrapotassic nor peralkaline, which are mandatory signatures by the IUGS to be termed them as bonafide lamproites. It is significant to note that lamproites from the EDC (Krishna, Ramadugu, Vattikod, and Cuddapah; Chalapathi Rao et al., 2004, 2010, 2014, 2016; Talukdar et al., 2018) are conspicuously devoid of perovskite, which is a ubiquitous phase in the recently reclassified 'lamproites' from the WKF, EDC. Likewise, all the EDC lamproites (Krishna, Ramadugu, Vattikod and Cuddapah) were generated from an ancient enriched lithospheric mantle, as suggested by their Sr-Nd isotopic compositions, whereas all the Mesoproterozoic ultramafic intrusions from the WKF tapped an isotopically more depleted source reflecting asthenospheric imprints. Tappe et al. (2018) 
also attested the asthenospheric component in kimberlite considering the Nd and Hf isotopic database of global occurrences. Many other prominent distinctions between kimberlites and lamproites were also summarized by Kononova et al. (2011).

Historically termed as micaceous kimberlites and subsequently christened as Group-II kimberlites and finally, as orangeites, these rocks share a closer resemblance with the lamproites as the mineralogical criteria established to distinguish orangeites as a separate group are now found to be not as robust as earlier thought of. Evolution of groundmass micas to a tetraferriphlogopite composition is used to distinguish them from kimberlites (Mitchell, 1995) but such evolutionary trends are also very common in lamproites (see Mitchell and Bergman, 1991). Moreover, out of the two magmatic trends of spinel evolution, the magmatic trend-2 is found to be common to both orangeites and lamproites (Dawson, 1987; Nixon, 1996). There's a similarity in their $\mathrm{Nd}-\mathrm{Sr}-\mathrm{Pb}$ isotopic content (Tainton and Browning, 1991; Tainton, 1992) as well suggesting that both were derived from a similar enriched source region within the continental lithospheric mantle. Interestingly, Nixon (1996) preferred to incorporate orangeites within the lamproite clan rather than to categorize them as another group of kimberlites. There is no denying fact that lamproites contain certain minerals, such as wadeite, priderite, zeppeite, which are unique to them. The role of metasomatism, degree of fractionation and wall-rock interaction also should be considered in evaluating the paragenesis of such exotic phases. For instance, crustal contamination of kimberlites can consequently increase the $\mathrm{SiO}_{2}$ content, which could also generate late-stage clinopyroxene (Chakmouradian and Mitchell, 2000), which is supposed to be present in orangeites only. Our present understanding of the KCRs is considerably influenced by studies from South Africa, Greenland, Canada and Australia which may not be necessarily valid globally. We subscribe to the views of Taylor and Kingdom (1999) and Chalapathi Rao (2005) that distinction amongst the KCRs for the time being should be attempted using the combined petrographic, mineralogical, geochemical and isotopic characters until a more robust mechanism of classification emerges.

\section{Future Directions}

We have provided an overview of the lamprophyre magmatism in various Indian cratons, mobile belts and associated with large igneous provinces through geological time. It can be seen that lamprophyres are widespread in the Indian shield and are found right from the Archaean to the Eocene. All the three world-wide known groups viz., alkaline, calc-alkaline and ultramafic as well as their varieties are also documented in the Indian shield. Calc-alkaline (including shoshonitic) varieties are essentially confined to the EDC whereas the ultramafic lamprophyres are confined to the rift zones such as the Kutch and the rift-related Mahakoshal belt. The calcalkaline lamprophyres from the EDC provide evidence for the involvement of Neoarchaean subduction-related processes in their genesis whereas the mixed orogenic-anorogenic characters displayed by some of the shoshonitic lamprophyres from EDC and Prakasam province can be explained by a subduction-accretion related metasomatism of the mantle edge, followed by the SCLM metasomatism by asthenospheric melts/fluids. The Gondwana lamprophyres are petrologically distinct in having combined characters of lamproites, kimberlites and aillikites. The Deccan lamprophyres carry a pronounced OIB-type trace element signature which is very likely an outcome of the influence of Reunion plume. Xenolith studies on the lamprophyres provided insights into the composition of the SCLM beneath the NW and western India and brought evidence for modal metasomatism and also constrained lithospheric thickness. Repeated lamprophyre emplacement in the Dongargaon domain highlights the reactivation of the Narmada rift zone during the Cretaceous. None of the Indian lamprophyres are diamondiferous even though microdiamond was suspected in some Gondwana lamprophyres. The potential of lamprophyres as important carriers of transition metals such as Co has only been recently realized from the microprobe study of pyrite from Sidhi lamprophyres. Future studies on Indian lamprophyres should focus on precise radiometric ages on phases such as rutile, titanite and apatite by deploying stateof-the-art techniques (such as LA-ICP-MS), which can give firm controls on the time of emplacement of lamprophyres and better constrain their geodynamic models. Direct dating of the phlogopite and apatite in mantle-derived xenoliths can provide the age of the metasomatism and unravel the agent resposible for it (i.e., Deccan plume or lamprophyre itself or both). Most of the known Indian lamprophyres are located either within the rift systems or along the deep-seated faults/fractures in association with the alkaline complexes demonstrating the role of structures in controlling their emplacement. Integration of geophysical studies along with hyper-spectral remote sensing can give insights into deep-seated structures like faults, fractures and rifts along which the lamprophyres would have been emplaced. The relationship of the lamprophyres to the Kimberlite clan rocks (KCRs), focusing on the Indian examples, is also critically examined and the pit-falls in the existing classification schemes in vogue are highlighted.

\section{Acknowledgements}

We thank Dr. Fareeduddin and Prof. Sarajit Sensarma for inviting us to contribute to this legacy volume of the IGC 2020 to be held at New Delhi. Critical review by two anonymous reviewers and editorial suggestions by Drs Fareeduddin and Sarajit Sensarma are thankfully acknowledged. This research work is an outcome of a major project (IR/S4/ESF-18/2011 dated 12.11.2013) sanctioned to NVCR by DSTSERB, New-Delhi. Fellowships by CSIR (to AS and AP) and by UGC (to RKG) are thankfully acknowledged.

\section{References}

Abdelfadil, K.M., Romer, R.L., Seifert, T., and Lobst, R., 2013, Calcalkaline lamprophyres from Lusatia (Germany)- Evidence for a repeatedly enriched mantle source. Chemical Geology, v. 353, pp. 230-245.

Andronikov, A.V., and Foley, S.F., 2001, Trace element and Nd-Sr isotopic composition of ultramafic lamprophyres from the East Antarctic Beaver Lake area. Chemical Geology, v. 175, pp. 291305.

Appavadhanulu, K., 1971, A short note on the lamprophyre dykes in parts of the Khammam district, Andhra Pradesh. Indian Minerals, v. 25, pp. 387-398.

Batki, A., Pál-Molnár, E., Dobosi, G., and Skelton, A., 2014, Petrogenetic significance of ocellar camptonite dykes in the Ditrãu Alkaline Massif, Romania. Lithos, v. 200-201, pp. 181-196.

Bhattacharya, A., Konglah, M.A., and Naik R.K., 2014, Mineral phase chemistry and petrogenesis of alkaline complex of Sidhi district, M.P. with preliminary appraisal of possible REE mineralization, 
Final Report of the field season 2012-13 and 2013-14. Geological Survey of India, pp.1-114.

Bose, M.K., and Dasgupta, D.K., 1973, Petrology of the alkali syenites of the Mundwara magmatic suite, Sirohi, Rajasthan, India. Geological Magazine, v. 110(5), pp. 457-466.

Bose, M.K., 1980, Alkaline magmatism in the Deccan Province. Journal of the Geological Society of India, v. 21, pp. 317-329.

Chakhmouradian, A.R., and Mitchell, H.R., 2000, Unusual accessory minerals in kimberlites of the Lac de Gras area (NWT, Canada): insight into the evolutionary history of the host rocks. Proceedings of the meeting Geological Association of Canada, Calagary.

Chalapathi Rao, N.V., 2008, Precambrian alkaline potassicultrapotassic, mafic-ultramafic magmatism in Peninsular India. Journal of the Geological Society of India, v. 72, pp. 57-84.

Chalapathi Rao, N.V., and Lehmann, B., 2011, Kimberlites, flood basalts and mantle plumes: New insights from the Deccan Large Igneous Province. Earth Science Reviews, v. 107, pp. 315-324.

Chalapathi Rao, N.V., Burgess, R., Lehmann, B., Mainkar, D., Pande, S.K., Hari, K.R., and Bodhankar, N., 2011, ${ }^{40} \mathrm{Ar} /{ }^{39} \mathrm{Ar}$ ages of mafic dykes from the Mesoproterozoic Chhattisgarh basin, Bastar craton, Central India: Implication for the origin and spatial extent of the Deccan Large Igneous Province. Lithos, v. 125, pp. 994-1005.

Chalapathi Rao, N.V., Dharma Rao, C.V., and Das, S., 2012, Petrogenesis of lamprophyres from Chhota Udepur area, Narmada rift zone and its relation to Deccan magmatism. Journal of Asian Earth Sciences, v. 45, pp. 24-39.

Chalapathi Rao, N.V., Gibson, S.A., Pyle, D.M., and Dickin, A.P., 2004, Petrogenesis of Proterozoic lamproites and kimberlites from the Cuddapah Basin and Dharwar craton, southern India. Journal of Petrology, v. 45(5), pp. 907-948.

Chalapathi Rao, N.V., Paton, C., and Lehmann, B., 2012, Origin and diamond prospectivity of Mesoproterozoic kimberlites from the Narayanpet field, Eastern Dharwar Craton, southern India: insights from groundmass mineralogy, bulk chemistry and perovskite oxybarometry. Geological Journal, v. 47(2-3), pp. 186-212.

Chalapathi Rao, N.V., Srivastava, R.K., Sinha, A.K., and Ravikant, V., 2014, Petrogenesis of Kerguelen mantle plume-linked Early Cretaceous ultrapotassic intrusive rocks from the Gondwana sedimentary basins, Damodar Valley, Eastern India. Earth-Science Reviews, v.136, pp. 96-120.

Chalapathi Rao, N.V., Wu, F.Y., Mitchell, R.H., Li, Q.L., and Lehmann, B., 2013, Mesoproterozoic U-Pb ages, trace element and $\mathrm{Sr}-\mathrm{Nd}$ isotopic composition of perovskite from kimberlites of the Eastern Dharwar craton, southern India: Distinct mantle sources and a widespread $1.1 \mathrm{Ga}$ tectonomagmatic event. Chemical Geology, v. 353, pp. 48-64.

Chalapathi Rao, N.V., 2005, A petrological and geochemical reappraisal of the mesoproterozoic diamondiferous Majhgawan pipe of central India: evidence for transitional kimberlite orangeite (group II kimberlite) - lamproite rock type. Mineralogy and Petrology, v. 84(2), pp. 69 -106.

Chawade, M.P., 1996, The petrology and geochemistry of dykes in Deccan basalts in parts of lower Narmada valley, around Chhaktala, Jhabua district, MP. Deccan basalts. Gondawana Geological Society, v. 2, pp. 185-200.

Currie K.L., and Williams, P.R., 1993, An Archean calc-alkaline lamprophyre suite, northeastern Yilgarn block, Western Australia. Lithos, v. 31, pp. 33-50.

Condie, K.C., 2005, High field strength element ratios in Archean basalts: a window to evolving sources of mantle plumes? Lithos, v. 79, pp. 491-504.

Dawson, J.B., 1987, The kimberlite clan: relationship with olivine and leucite lamproites, and inferences for upper-mantle metasomatism. Geological Society, London, Special Publications, v. 30(1), pp. 95-101.

Delor, C.P., and Rock, N.M.S., 1991, Alkaline-ultramafic lamprophyre dykes from the Vestfold Hills, Princess Elizabeth Land (East Antarctica): primitive magmas of deep mantle origin. Antarctic Science, v. 3, pp. 419-432.

Deshpande, G.G., and Chakranaryana, A.B., 1973, Occurences of lamprophyre near Murud- Janjira, Kolba district, Maharashtra, India. Current Science, v. 42, pp. 404-405.

Dessai, A.G., and Viegas, A., 2010, Petrogenesis of alkaline rocks from Murud-Janjira, in the Deccan Traps, Western India. Mineralogy and Petrology, v. 98, pp. 297-311.

Dessai, A.G., Markwick A., Vaselli, O., and Downes, H., 2004, Granulite and Pyroxenite xenoliths from the Deccan Trap: insight into the nature and composition of the lower lithosphere beneath cratonic India. Lithos, v. 78, pp. 236-290.

Dessai A.G., Rock N.M.S., Griffin B.J., and Gupta, D.,1990, Mineralogy and petrology of some xenolth bearing alkaline dykes associated with Deccan magmatism, south of Bombay, India. European Journal of Mineralogy, v. 2, pp. 667- 685.

Devaraju, T.C., Laajoki, L., Zozulya, D., Khandali, S.D., and Ugarkar, A.G. 1995, Neo- Proterozoic dyke swarms of south Karnataka. Part II: Geochemistry, Oxygen isotopic composition, Rb-Sr age and petrogenesis. Memoirs of Geological Society of India, v. 33, pp. 267-303.

Dongre, A., and Tappe, S., 2019, Kimberlite and carbonatite dykes within the Premier diatreme root (Cullinan Diamond Mine, South Africa): New insights to mineralogical-genetic classifications and magma $\mathrm{CO}_{2}$ degassing. Lithos, v. 338, 155-173.

Dongre, A., Viljoen, K.S., Belyanin, G., Le-Roux, P., and Malandkar, M., 2019, Petrogenesis of the diamondiferous Pipe-8 ultramafic intrusion from the Wajrakarur kimberlite field of Southern India and its relation to the worldwide Mesoproterozoic ( 1.1 Ga) magmatism of kimberlite and related rocks. Geoscience Frontiers, https://doi.org/10.1016/j.gsf.2019.07.010.

Dostal, J., Keppie, J.D., Hamilton, M.A., Aarabs, E.M., Leforts, J.P., and Murphy, J.B., 2005, Crustal xenoliths in Triassic lamprophyre dike in western Morocco: tectonic implications for the Rheic Ocean suture. Geological Magazine, v. 142, pp. 159-172.

Durgadhmath, M.B., 1984, Lamprophyre dykes from Phenai-Mata area Baroda district, Gujrat. Geological Survey of India Special Publication, v. 12, pp. 3-6.

Evans, J.W., 1901, A monchiquite from Mount Girnar, Junagarh (Kathiawar), Quaterly Journal of Geological Society, v. 57, pp. 38-54.

Fareeduddin, and Mitchell, R.M., 2012, Diamonds and Their Source Rocks in India. Geological Society of India, Bangalore, pp. 434.

Fareeduddin, Kirmani, I.R., Srivastava, B.L., Reddy, A.B., and Bhattacharjee, J., 1995, Lamprophyre dykes in the South Delhi fold belt near Pipela, district Sirohi, Rajasthan. Journal of the Geological Society of India, v. 46, pp. 255-261.

Fitzpayne, A., Giuliani, A., Mass, R., Hergt, J., Janney, P., and Phillips, D., Progressive metasomatism of the mantle by kimberlite melts: Sr-Nd-Hf-Pb isotope compositions of MARID and PIC minerals. Earth and Planetary Science Letters, v. 509, pp. 15-26.

Foley, S.F., Andronikov, A.V., and Melzer, S., 2002, Petrology of ultramafic lamprophyres from the Beaver lake area of Eastern Antartica and their relation to the breakup of Gondwanaland. Mineralogy and Petrology, v. 74, pp. 361-384.

Foley, S.F., Yaxley, G.M., Rosenthal, A., Buhre, S., Kiseeva, E.S., Rapp, R.P., and Jacob, D.E., 2009, The composition of nearsolidus melts of peridotite in the presence of $\mathrm{CO}_{2}$ and $\mathrm{H}_{2} \mathrm{O}$ between 40 and 60 kbar. Lithos, v. 112, pp. 274-283.

Francis, D., and Patterson, M., 2010, Reply to the Discussion by Mitchell and Tappe on "Kimberlites and aillikites as probes of 
the continental lithospheric mantle”. Lithos, v. 115(1-4), pp. 293295.

Garza, A.O., Dostal, J., Keppie, J.D., Paz-Moreno, F.A., 2013, MidTertiary (25-21 Ma) lamprophyres in NW Mexico derived from subduction-modified subcontinental lithospheric mantle in an extensional backarc environment following steepening of the Benioff zone. Tectonophysics, v. 590, pp. 59-71.

Giri, R.K., Pandit, D., and Chalapathi Rao, N.V., 2018, Cobaltoan pyrite in a lamprophyre from the Sidhi gnessic complex, Mahakoshal Belt, Central India. Journal of Geological Society of India, v. 91, pp. 5-8.

Giri, R.K., Pankaj, P., Chalapathi Rao, N.V., Chakrabarti, R. and Pandit, D., 2019. Petrogenesis of an alkaline lamprophyre (camptonite) with ocean island basalt (OIB) affinity at the NW margin of the Cuddapah basin, Eastern Dharwar craton, southern India. Neues Jahrbuch Fur Mineralogie Abhandlungen , v. 196/ 2, pp. 149-177.

Guo, F., Fan, W., Wang, Y., and Zhang, M., 2004, Origin of early Cretaceous calc-alkaline lamprophyres from the Sulu orogen in eastern China: implications for enrichment processes beneath continental collisional belt. Lithos, v. 78, pp. 291-305.

Gwalani, L.G., Rock, N.M.S., Chang, W.J., Fernandez, S., Allegre, C.J. and Prinzhofer, A., 1993, Alkaline Rocks and Carbonatites of Amba Dongar and Adjacent Areas, Deccan Igneous Province, Gujarat, India: 1. Geology, Petrography and Petrochemistry. Mineralogy and Petrology, v. 47, pp. 219-253.

Haggerty, S. E., and Birkett, T., 2004, Geological setting and chemistry of kimberlite clan rocks in the Dharwar Craton, India. Lithos, v. 76(1-4), pp. 535-549.

Hari, K.R., 1998, Mineralogical and Petrological studies of the Lamprophyres around Chaktalao area, Madhya Pradesh. Journal of the Geological Society of India, v. 51, pp. 21-30.

Hari, K.R., Satish Kumar, M., Santosh, M., and Rai, S.K., 2000, Melt inclusions in olivines and pyroxene phenocrysts from lamprophyres from Chhaktalao area, Madhya Pradesh, India. Journal of Asian Earth Sciences, v. 18, pp. 155-161.

Hofmann, A.W., Jochum, K.P., Seufert, M., and White, W.M., 1986, $\mathrm{Nb}$ and $\mathrm{Pb}$ in oceanic basalts: new constraints on mantle evolution. Earth and Planetary Science Letters, v. 79, pp. 33-45.

Jaitly, A.K., Karkare, S.G., and Singh, C.S.P., 1980, Igneous rocks associated with Bajocian sediments of Kala Dongar, Patcham Island, Kachchh, Bulletin of Earth Sciences (Pune), v. 8, pp. 16.

Jayananda, M., Santosh, M., and Aadhiseshan K.R., 2018, Formation of Archean (3600-2500 Ma) continental crust in the Dharwar Craton, southern India. Earth Science Reviews, v. 181, pp. 1242.

Jia, Y., Kerrich, R., Gupta, A.K., and Fyfe, W.S., 2003, 15 N-enriched Gondwana lamproites, eastern India: crustal $\mathrm{N}$ in mantle source. Earth and Planetary Science Letters, v. 215, pp. 43-56.

Karmalkar, N.R., Duraiswami, R.A., Jonnalagadda, M.K., and Griffin, W.L., 2014, Mid-Cretaceous lamproite fromthe Kutch region, Gujarat, India: Genesis and tectonic implications. Gondwana Research, v. 26, pp. 942-956.

Kaur, G., and Mitchell, R.H., 2013, Mineralogy of the P2-West 'Kimberlite', Wajrakarur kimberlite field, Andhra Pradesh, India: kimberlite or lamproite?. Mineralogical Magazine, v. 77 (8), pp. 3175-3186.

Kaur, G., and Mitchell, R.H., 2016, Mineralogy of the P-12 K-Tirichterite diopside olivine lamproite from Wajrakarur, Andhra Pradesh, India: implications for subduction-related magmatism in eastern India. Mineralogy and Petrology, v. 110 (2-3), pp. 223245.

Kaur, G.,Korakoppa, M., and Pruseth, K.L., 2013, Petrology of P-5 and P-13 "Kimberlites" from Lattavaram Kimberlite Cluster, Wajrakarur Kimberlite Field, Andhra Pradesh, India: Reclassification as Lamproites. In: Pearson D. et al. (eds) Proceedings of 10th International Kimberlite Conference. Springer, pp. 183-194.

Kononova, V.A., Bogatikov, O.A., and Kondrashov, I.A., 2011, Kimberlites and lamproites: Criteria for similarity and differences. Petrology, v. 19(1), pp. 34-54.

Kent, R.W., Kelly, S.P., and Pringle, M.S., 1998, ${ }^{40} \mathrm{Ar} /{ }^{39} \mathrm{Ar}$ geochronology of orangeites (Group 2 Kimberlites) from the Damodar Valley, eastern India. Mineralogical Magazine, v. 62, pp. 313-323.

Kerr, A.C., Khan, M., Mahoney, J.J., Nicholson, K.N., and Hall, C.M., 2010, Late Cretaceous alkaline sills of the south Tethyan suture zone, Pakistan: initial melts of the Réunion hotspot?. Lithos, v. 117, pp. 161-171.

Khan, S., Dongre, A., Viljoen, F., Li, Q-L. and Roux, P.L. 2018, Petrogenesis of lamprophyres synchronous to kimberlites from the wajrakarur kimberlite field: Implication for contrasting lithospheric mantle sources and geodynamic evolution of the eastern Dharwar craton of southern India. Geological Journal, pp. 1-23.

Kirmani, I.R., and Fareeduddin, 2008, Geochemistry of the differentiated lamprophyre dyke, South Delhi fold belt, Pipela area, district Sirohi, Rajasthan. Journal of the Geological Society of India, v. 56, pp. 615-623.

Krmíček, L., Cempírek, J., Havlín, A., Pøichystal, A., Houzar, S., Krmíčková, M., Gadas, P., 2011, Mineralogy and petrogenesis of a Ba-Ti-Zr-rich peralkaline dyke from Šebkovice (Czech Republic): recognition of the most lamproitic Variscan intrusion. Lithos, v. 121, pp. 74-86.

Krmíček, L., Romer, R.L., Ulrych, J., Glodny, J., and Preleviæ, D., 2016, Petrogenesis of orogenic lamproites of the Bohemian Massif: $\mathrm{Sr}-\mathrm{Nd}-\mathrm{Pb}-\mathrm{Li}$ isotope constraints for Variscan enrichment of ultra-depleted mantle domains. Gondwana Research, v. 35, pp. 198-216.

Kumar, A., Dayal, A.M., and Padmakumari, V.M., 2003, Kimberlite from Rajmahal magmatic province: $\mathrm{Sr}-\mathrm{Nd}-\mathrm{Pb}$ isotopic evidence for Kerguelen plume derived magmas. Geophysical Research Letter, v. 30, pp. 2053.

Lanjewar, S., and Randive, K., 2017, Lamprophyres from the Harohalli dyke swarm in the Halaguru and Mysore areas, Southern India: Implications for backarc basin magmatism. Journal of Asian Earth Sciences, v. 157, pp. 329-347.

Leat, P.T., Riley, T.R., Storey, B.C., Kelley, S.P., and Millar, I.L., 2000, Middle Jurassic ultramafic lamprophyre dyke within the Ferrar magmatic province, Pensacola Mountains, Antarctica. Mineralogical Magazine, v. 64, pp. 95-111.

Leelanandam, C., and Ratnakar, J., 1980, Occurrence of ocellar lamprophyres from the Purimetla pluton, Prakasam district, Andhra Pradesh. The Quarterly Journal of the Geological, Mining, and Mettalurgical Society of India, v. 52, pp. 77- 79.

Leelanandam, C., and Srinivasan, T.P., 1986, Ocellar lamprophyres in the Settupalle alkaline pluton, Prakasam district, Andhra Pradesh. Current Science, v. 55, pp. 474-476.

Luhr, J.F., Allan, J.F., Carmichael, I.S.E., Nelson, S.A., and Hasenaka, T., 1989. Primitive calc alkaline and alkaline rock types from the western Mexican volcanic belt. Journal of Geophysical Research, v. 94, pp. 4515-4530.

Madhavan, V., Mallikharjuna Rao, J., Balaram, V., and Kumar, R., 1992, Geochemistry and petrogenesis of lamprophyres associated dykes from Elchuru, Andhra Pradesh. Journal Geological Society of India, v. 40, pp. 135-149.

Madhavan, V., David, K., Mallikharjuna Rao, J., Chalapathi Rao, 
N.V., and Srinivas, M., 1998, Comparative study of lamprophyres from the Cuddapah Intrusive Province (CIP) of Andhra Pradesh, India. Journal of Geological Society of India, v. 52, pp. 621-642.

Mahoney, J.J., Macdougall, J.D., Lugmair, G.W., Gopalan, K. and Krishnamurthy, P., 1985, Origin of contemporaneous tholeiitic and K-rich alkalic lavas: case study from the northern Deccan Plateau, India. Earth and Planetary Science Letters, v. 72, pp. 3953.

Mahotkin, I. L., Gibson, S. A., Thompson, R. N., Zhuravlev, D. Z., and Zherdev, P. U., 2000, Late Devonian diamondiferous kimberlite and alkaline picrite (proto-kimberlite?) magmatism in the Arkhangelsk region, NW Russia. Journal of Petrology, v. 41(2), pp. 201-227.

Melluso, L., Sethna, S.F., Antonio, M.D., Javeri, P., and Bennio, L., 2002, Geochemistry and petrogenesis of sodic and potassic mafic alkaline rocks in the Deccan Volcanic Province, Mumbai area (India). Mineralogy and Petrology, v. 74, pp. 323-342.

Meshram, T.M., Shukla, D., and Behera, K.K., 2015, Alkaline lamprophyre (camptonite) from Bayyaram area, NE margin of the Eastern Dharwar Craton, southern India. Current Science, v. 109, pp. 1931-1934.

Meshram, R.R., Dora, M.L., Naik, R., Shareef, M., Gopalkrishna, G., Meshram, T., Baswani, S.R., and Randive, K.R., 2018, A new find of calc-alkaline lamprophyres in Thaneswana area, Western Bastar Craton, India. Journal of Earth System Sciences, v. 128(1), https://doi.org/10.1007/s12040-018-1037-x.

Mitchell, R. H., 1995, Kimberlites, Orangeites and Related Rocks. New York: Plenum, pp. 406

Mitchell, R., and Tappe, S., 2010, Discussion of "Kimberlites and aillikites as probes of the continental lithospheric mantle", by D. Francis and M. Patterson. Lithos, v. 109(1-4), p. 72-80.

Muller, D. and Groves, D.I., 2019, Tectonic settings of Potassic Igneous rocks In: Potassic Igneous Rocks and Associated GoldCopper Mineralization. Mineral Resource Reviews. Springer, https://doi.org/10.1007/978-3-319-92979-8_3.

Nair, K.K.K., Jain S.C., and Yedekar, D.B., 1995, Stratigraphy, structure and geochemistry of the mahakoshal greenstone belt; Geological Survey of India Memoir, v. 31, pp. 403-432.

Nambiar, A.R., 2007, Early Cretaceous lamprophyre dykes from Nongchram fault zone, Meghalaya, North eastern India. Journal of Geological Society of India, v. 69, pp. 641-652.

Nambiar, A.R., 1988, Petrology of lamprophyres from parts of east Garo Hills and west Khasi Hills district, Meghalaya. Journal of the Geological Society of India, v. 32, pp. 81-83.

Nasir, S., 2016, Petrology of Late Jurassic allochthonous Ultra Mafic Lamprophyre within the Batain Nappes, Northeastern Oman, International Geology Review, v. 58(8), pp. 913-928.

Navaneethakrishnan, C., and Chandrasekharan, C.G., 1994, Camptonite dyke from the Pikkilialkaline complex, Dharmapuri district, Tamil Nadu. Current Science, v. 67, pp. 44-46.

Nixon PH (1996) Book review of "Mitchell RH (1995) Kimberlites, orangeites and related rocks. Plenum Press, New York, 406 pp”. Mineralogical Magazine, v. 60, pp. 358-359.

Orejana, D., Villaseca, C., and Paterson, B.A., 2006, Geochemistry of pyroxenitic and hornblenditic xenoliths in alkaline lamprophyres from the Spanish Central System. Lithos, v. 86(12), pp. 167-196.

Orejana, D., Villaseca, C., Billström, K., and Paterson, B.A., 2008, Petrogenesis of Permian alkaline lamprophyres and diabases from the Spanish Central System and their geodynamic context within western Europe. Contributions to Mineralogy and Petrology, v. 156, pp. 477-500.

Owen, J.P., 2008, Geochemistry of lamprophyres from the Western Alps, Italy: implications for the origin of an enriched isotopic component in the Italian mantle. Contributions to Mineralogy and Petrology, v. 155, pp. 341-362.

Pandey, R., Chalapathi Rao, N.V., Dhote, P., Pandit, D., Choudhary, A.K., Sahoo, S., and Lehmann, B., 2018a, Rift-associated ultramafic lamprophyre (damtjernite) from the middle part of the Lower Cretaceous (125 Ma) succession of Kutch, northwestern India: Tectonomagmatic implications. Geoscience Frontiers, v. 9, pp. 1883-1902.

Pandey, A., Chalapathi Rao, N.V., Pandit, D., Pankaj, P., Pandey, R., Sahoo, S., and Kumar, A., 2017a, Subduction tectonics in the evolution of the eastern Dharwar craton, southern India: Insights from the post-collisional calc-alkaline lamprophyres at the western margin of the Cuddapah basin. Precambrian Research, v. 298, pp. 235-251.

Pandey, A., Chalapathi Rao, N.V., Chakrabarti, R., Pandit, D., Pankaj, P., Kumar, A., and Sahoo, S., 2017b, Petrogenesis of a Mesoproterozoic shoshonitic lamprophyre dyke from the Wajrakarur kimberlite field, southern India: Geochemical and Sr$\mathrm{Nd}$ isotopic evidence for a modified sub-continental lithospheric mantle source. Lithos, v. 292-293, pp. 218-233.

Pandey, R., Chalapathi Rao, N.V., Pandit, D., Sahoo, S., and Dhote, P., 2017c, Imprints of modal metasomatism in the post-Deccan subcontinental lithospheric mantle: petrological evidence from an ultramafic xenolith in an Eocene lamprophyre, NW India. Geological Society London Special Publication, v. 463, pp.

Pandey, A., Chalapathi Rao, N.V., Chakrabarti, R., Pankaj, P., Kumar, A., Pandit, D., Pandey, R., and Sahoo, S., 2018b, Post-collisional calc-alkaline lamprophyres from the Kadiri greenstone belt: Evidence for the Neoarchean convergence related evolution of the Eastern Dharwar Craton and its schist belts. Lithos, v. 320321, pp. 105-117.

Pandey, R., Sahoo, S., Pandit, D., Pandey, M., and Chalapathi Rao, N.V., 2018c, Recurrent lamprophyre magmatism in the Narmada rift zone: Petrographic and mineral chemistry evidence from xenoliths in the Eocene Dongargaon lamprophyre, NW Deccan large igneous province, India. Journal of the Indian Institute of Science, v. 98(4), 401-415.

Pandey, R., Pandey, A., Chalapathi Rao, N.V., Belyatsky, B., Choudhary, A.K., Lehmann, B., Pandit, D., Dhote, P., 2019, Petrogenesis of end-Cretaceous/Early Eocene lamprophyres from the Deccan Large Igneous Province: Constraints on plumelithosphere interaction and the post-Deccan lithosphereasthenosphere boundary (LAB) beneath NW India. Lithos, v. 346347, 105139.

Paul, D.K., 1991, Indian kimberlites and lamprophyres: Mineralogical and chemical aspects. Journal of the Geological Society of India, v. 37, pp. 221-238.

Paul D.K., and Potts P.J., 1981, Rare earth abundances and origin of some Indian Lamprophyres. Geological Magazine, v. 118, pp. 393-399.

Paul, D.K., and Sarkar, A., 1984, Petrogenesis of some Indian lamprophyres, Special Publication Geological Survey of India, v. 12, pp. 45-54.

Paul D.K., Potts P.J., Rex, D.C., and Beckinsale, R.D., 1977, Geochemical and petrogenetic study of the Girnar igneous complex, Deccan Volcanic Provinces, India. Bulletin Geological Society of America, v. 88, pp. 227-34.

Pearce, J.A., 2008, Geochemical fingerprinting of oceanic basalts with applications to ophiolite classification and the search for Archean oceanic crust. Lithos, v. 100, pp. 14-48.

Queen, M., Heaman, L.M., Hanes, J.A., Archibald, D.A., Farrar, E., 1996. 40Ar/39Ar phlogopite and U-Pb perovskite dating of lamprophyre dykes from eastern Lake Superior region: evidence for a 1.14 Ga magmatic precursor to Midcontinental Rift 
volcanism. Canadian Journal of Earth Science, v. 33, pp. 958965.

Rao, R.B.N., 1939, Hornblende lamprophyre dykes near Yachenahalli, Mysore district. Records of Mysore Geological Department, v. 37, pp. 117-120.

Raghuvanshi, S., Pandey, A., Pankaj, P., Chalapathi Rao, N.V., Chakrabarti, R., Pandit, D., Pandey, R., 2019. Lithosphereasthenosphere interaction and carbonatite metasomatism in the genesis of Mesoproterozoic shoshonitic lamprophyres at Korakkodu, Wajrakarur kimberlite field, Eastern Dharwar Craton, southern India. Geological Journal, https://doi.org/10.1002/ gj.3468.

Randive, K.K., Sahu, M.K., Lanjewar, S. and Belyatsky, Eocene ( 55 Ma) Age for the Lamprophyre Dyke of Chota Udaipur CabonatiteAlkaline Subprovince, Lower Narmada Valley, Gujarat and Madhya Pradesh States, India, Conference: 10th International Kimberlite Conference, At Bangalore, India, Volume: Short Abstracts, 2012.

Randive, K.R., Prasad, G.J.S., Anil Kumar, A., Rama Rao, R., Bhaskar Rao, Y.J., and Dayal, A.M., 2005. Picrobasalt and lamprophyre dyke swarm of Bakhatgarh-Phulmal area, Chhota Udaipur alkaline Complex, Deccan Igneous Complex. Indian Journal of Geochemistry, v. 20, pp. 191-212.

Ratnakar, J., Ramakrishna, D.V., and Vijaya Kumar, K., 1996, Geochemistry and origin of Kellampalle lamprophyre, Prakasam Province, Andhra Pradesh. Journal of Geological Society of India, v. 48, pp. 697-702.

Ratnakar, J., Ramakrishna, D.V., Vijaya Kumar, K., and NagsaiSarma, V., 1995, An alkaline lamprophyre (camptonite) from Ravipadu, Prakasam province, Andhra Pradesh, India. Current Science, v. 68, pp. 956-959.

Ratnakar, J., Ramakrishna, D.V., Vijaya Kumar, K., and Nagsaisarma, V., 1992, A new occurrence of alkaline lamprophyre near Kellampalle, Prakasam district, Andhra Pradesh, India. Current Science, v. 63, pp. 569-570.

Ray, J.S., and Pande, K., 1999, Carbonatite alkaline magmatism associated with continental flood basalts at stratigraphic boundaries: Cause for mass extinctions. Geophysical Research Letters, v. 26(13), pp. 1917-1920.

Reddy, T. A. K., 1987, Kimberlite and lamproite rocks of Wajrakarur area, Andhra Pradesh. Journal of the Geological Society of India, v. 30(1), pp. 1-12.

Riley, T.R., Leat, P.T., Storey B.C., Parkinson, I.J., and Millar, I.L., 2003, Ultramafic lamprophyres of the Ferrar large igneous province: evidence for a HIMU mantle component. Lithos, v. 66, pp. 63-76.

Ringwood, A. E., Kesson, S. E., Hibberson, W., and Ware, N., 1992, Origin of kimberlites and related magmas. Earth and Planetary Science Letters, v. 113(4), pp. 521-538.

Rock N.M.S., 1977, The nature and origin of lamprophyres: some definitions, distinctions and derivations. Earth Science Reviews, v. 13, pp. 123-169.

Rock, N.M.S. and Paul, D.K., 1989, "Lamprophyres", "lamproites" and "kimberlites" in India: a bibliography and preliminary reappraisal. Memoirs Geological Society of India, v. 15, pp. 291311.

Rock, N.M.S., Griffin, B.J., Edgar, A.D., Paul, D.K., and Hergt, J.M., 1992. A spectrum of potentially diamondiferous lamproites and minettes from the Jharia coalfield, eastern India. Journal of Volcanology and Geothermal Research, v. 50, pp. 55-83.

Rock N.M.S., 1986, The Nature and Origin of Ultramafic Lamprophyres: alnoites and allied rocks. Journal of Petrology, v. 27, pp. 155-196.

Rock, N.M.S., 1987. The nature and origin of lamprophyres: an overview. In: Fitton, J.G., Upton, B.G.J. (Eds.), Alkaline Igneous Rocks. Geological Society Special Publications, 30. Geological Society of London, United Kingdom, pp. 191-226.

Rock, N.M.S. 1991, Lamprophyres, Blackie and Sons Ltd., Glasgow, pp. 287.

Roy, A., and Bandyopadhyay, B.K., 1988, Tectonic significance of ultramafic and associated rocks near Tal in the Bijawar belt, Sidhi district, Madhya Pradesh. Journal of the Geological Society of India, v. 32, pp. 397-410.

Sadashivaiah, M.S., and Durgadmath,M.B., 1976, Camptonite dykes from Phenai Mata area, Baroda district, Gujrat state, India, The Karnatak University Journal of Science, v. 21.

Saravanan and Ramasamy, 1995, Geochemistry and Petrogenesis of Shonkinite and associated Alkaline rocks of Tiruppattur Carbonatite Complex, Tamil Nadu. Journal of the Geological Society of India, v. 46, pp. 235-243.

Satyanarayanan, M., Rao, D.V.S., Renjith, M.L., Singh, S.P., Babu, E.V.S.S.K., and Korakoppa, M.M., 2017, Petrogenesis of carbonatitic lamproitic dykes from Sidhi gneissic complex, Central India. Geoscience Frontiers, https://doi.org/10.1016/ j.gsf.2017.04.011.

Shaikh, A.M., Patel, S.C., Ravi, S., Behera, D., Pruseth, K.L., 2017, Mineralogy of the TK1 and TK4 'kimberlites' in the Timmasamudram cluster, Wajrakarur Kimberlite Field, India: Implications for lamproite magmatism in a field of kimberlites and ultramafic lamprophyres. Chemical Geology, v. 455, pp. 208230.

Shaikh, A. M., Kumar, S. P., Patel, S. C., Thakur, S. S., Ravi, S., and Behera, D., 2018, The P3 kimberlite and P4 lamproite, Wajrakarur kimberlite field, India: mineralogy, and major and minor element compositions of olivines as records of their phenocrystic vs xenocrystic origin. Mineralogy and Petrology, v. 112(2), pp. 609624.

Sen, G., Bizimis, M., Das R., Paul, D.K., Ray, A., and Biswas, S., 2009, Deccan plume, lithosphere rifting, and volcanism in Kutch, India. Earth and Planetary Science Letters, v. 277, pp. 101-111.

Sharma, A., Kumar, D., Sahoo, S., Pandit, D., and Chalapathi Rao, N.V., 2018, Chrome-diopside megacryst lamprophyre from the Late cretaceous mundwara alkaline complex, NW India: petrological and geodynamical implications. Journal of the Geological Society of India, v. 91, pp. 5-8.

Singh, U.P., Venkatesh, N.S., Godhavari, K.S., Gopalakrishanan, R., Fareeduddin and Rao, M.S., 2004, Lamprophyre Dykes in Chotanagpur Gneissic Complex, Near Simdega District, Jharkhand. Journal of the Geological Society of India, v. 63, pp. 655-658.

Sinha, A.K., Sankaran, A.V., and Bhattacharyya, T.K., 1973, Geochemistry of newer dolerite suite of intrusion within the Singhbum granite: a preliminary study. Journal of the Geological Society of India, v. 14, pp. 329-346.

Scott Smith, B., 1989, Lamproites and kimberlites in India. Neues Jahrbuch Fur Mineralogie-Abhandlungen, v. 161(2), pp. 193-225.

Smith, C. B., Haggerty, S. E., Chatterjee, B., Beard, A., and Townend, R. (2013), Kimberlite, lamproite, ultramafic lamprophyre, and carbonatite relationships on the Dharwar Craton, India; an example from the Khaderpet pipe, a diamondiferous ultramafic with associated carbonatite intrusion. Lithos, v. 182, pp. 102113.

Srikarni, C., and Das, S., 2005, A record of lamprophyric rocks around Chhota Udepur, Vadodara district and its petrological and geological comparison with other occurrences of lamprophyres in Gujarat. Indian Minerals, v. 59, pp. 31-38.

Srivastava, R.K., and Chalapathi Rao, N.V., 2007, Petrology, geochemistry and tectonic significance of Palaeoproterozoic 
alkaline lamprophyres from the Jungel Valley, Mahakoshal supracrustal belt, Central India. Mineralogy and Petrology, v. 89, pp.189-215.

Srivastava, R. K., Chalapathi Rao, N.V., and Sinha, A.K., 2009, Cretaceous alkaline intrusives with affinities to aillikites from the Jharia area: Magmatic expression of metasomatically veined and thinned lithospheric mantle beneath the Singhbhum Craton, Eastern India. Lithos, v. 112S, pp. 407-418.

Srivastava, R.K., 2013, Petrological and geochemical characteristics of Paleoproterozoic ultramafic lamprophyres and carbonatites from the Chitrangi region, Mahakoshal supracrustal belt, central India. Journal of Earth System Sciences, v. 122, pp. 759-776.

Srivastava, R.K., Melluso, L., and Sinha, A.K., 2016, Petrogenesis of an early Cretaceous potassic lamprophyre dyke from Rongjeng, East Garo Hills, Shillong plateau, north-eastern India. Current Science, v. 110, pp. 649-658.

Stoppa, F., Rukhlov, A.S., Bell, K., Schiazza, M., and Vichi, G., 2014, Lamprophyres of Italy: early Cretaceous alkaline lamprophyres of Southern Tuscany, Italy. Lithos, v. 188, pp. 97-112.

Subba Rao, K.V., 1971, The Kunavaram series- A group of alkaline rocks Khammam district, Andhra Pradesh, India. Journal of Petrology, v. 12, pp. 624-641.

Subba Rao, T.V., Bhaskar Rao, Y.J., Srinivasan, R. and Goplan, K., 1989,Rb-Sr age and petrology of the Elchuru alkaline complex; Implications to alkaline magmatism in the Eastern Ghats mobile belt. Memoirs of the Geological Society of India, v. 15, pp. 207223.

Subba Rao, S., 1972, Alkaline rocks of the Deccan traps. Bulletin Volcanologie, v. 35, pp. 983-997.

Sugavanam, E.B., Mallikharjuna, C., and Vidhyadharan, K.T., 1994, Archaean meta lamprophyres from Nuggihalli schist belt, Hassan district- Karnataka. Journal of the Geological Society of India, v. 43, pp. 115-137.

Sukheswala, R.N., and Avasia, R.K., 1972, Carbonatite-alkaline complex of Panwad-Kaimut, Gujrat, Bulletin of Volcanology, v. 35, pp. 564-578.

Sukheswala, R.N., and Sethna, S.F., 1962, Deccan trap and associated rocks of the Bassein area. Journal of the Geological Society of India, v. 3, pp. 125-46.

Sun, C., M., Bertrad, J., 1991, Geochemistry of clinopyroxenes in plutonic and volcanic sequences from the Yanbian Proterozoic ophiolites (Sichuan province, China): Petrogenetic and geotectonic implications. Schweiz. Mineral. Petrog. Mitt., v. 71, pp. 243-259.

Sun, S.S., and McDonough, W.F., 1989, Chemical and isotopic systematics of oceanic basalts: implications for mantle composition and processes. In: Saunders, A.D., Norry, M.J. (Eds.), Magmatism in Ocean Basins. Geological Society of London, Special Publication, v. 42, pp. 313-345.

Tainton, K. M., 1992, The petrogenesis of group-2 kimberlites and lamproites from the Northern Cape Province, South Africa (Doctoral dissertation, University of Cambridge).

Tainton, K. M., and Browning, P., 1991, The Group-2-KimberliteLamproite Connection: Some Constraints from the Barkly-West District, Northern Cape Province, South Africa. In International Kimberlite Conference: Extended Abstracts, V. 5, pp. 405-407.
Talukdar, D., Pandey, A., Chalapathi Rao, N.V., Kumar, A., Pandit, D., Belyatsky, B.V., and Lehmann, B., 2018, Petrology and geochemistry of the Mesoproterozoic Vattikod lamproites, Eastern Dharwar Craton, southern India: evidence for multiple enrichment of sub-continental lithospheric mantle and links with amalgamation and break-up of the Columbia supercontinent. Contributions to Mineralogy and Petrology, v. 173, https://doi.org/ 10.1007/s00410-018-1493-y.

Tappe, S., Jenner, G.A., Foley,S.F., Heaman, L., Besserer, D., Kjarsgaard, B.A., and Ryan, B., 2004, Torngat ultramafic lamprophyres and their relation to North Atlantic Alkaline Province. Lithos, v. 76, pp. 491-518.

Tappe, S., Foley, S. F., Jenner, G. A., and Kjarsgaard, B. A. 2005, Integrating ultramafic lamprophyres into the IUGS classification of igneous rocks: rationale and implications. Journal of Petrology, v. 46(9), pp. 1893-1900.

Tappe, S., Foley, S.F., Jenner, G.A., Heaman, L.M., Kjarsgaard, B.A., Romer, R.L., Stracke, A., Joyce, N., and Hoefs, J., 2006, Genesis of ultramafic lamprophyres and carbonatites at Aillik Bay, Labrador: a consequence of incipient lithospheric thinning beneath the North Atlantic craton. Journal of Petrology, v. 47, pp. 12611315.

Tappe, S., Smart, K., Torsvik, T., Massuyeau, M., and de Wit, M., 2018, Geodynamics of kimberlites on a cooling Earth: Clues to plate tectonic evolution and deep volatile cycles. Earth and Planetary Science Letters, v. 484, pp. 1-14.

Tappe, S., Steenfelt, A., Heaman, L. M., and Simonetti, A. 2009, The newly discovered Jurassic Tikiusaaq carbonatite-aillikite occurrence, West Greenland, and some remarks on carbonatitekimberlite relationships. Lithos, v. 112, pp. 385-399.

Taylor, W.R. and Kingdom, L.1999. Mineralogy of the Jagersfontein kimberlite - an unusual group 1 micaceous kimberlite - and a comment on the robustness of the mineralogical definition of 'orangeite'. International Kimberlite Conference: Extended Abstracts, 7(1), 892-894, https://doi.org/10.29173/ikc2921.

Ulrych, J., Adamoviè, J., Krmíèek, L., Ackerman, L., and Balogh, K., 2014, Revision of Scheumann's classification of melilitic lamprophyres and related melilitic rocks in light of new analytical data. Journal of Geoscience, v. 59(1), pp. 3-22.

Upadhyay, D., Raith, M.M., Mezger, K., and Hammerschmidt, K., 2006, Mesoproterozoic rift-related alkaline magmatism at Elchuru, Prakasam Alkaline Praovince, SE India. Lithos, v. 89, pp. 447-477.

Vijaya Kumar, K., and Rathna, K., 2008, Geochemistry of the mafic dykes in the Prakasam Alkaline Province of Eastern Ghats Belt, India: Implications for the genesis of continental rift-zone magmatism. Lithos, v. 104, pp. 306-326.

Vinod Kumar, 1995, Petrography, geochemistry and petrogenesis of alkali lamprophyres of Jungel suite, Central India. Journal of Geological Society of India, v. 45, pp. 263-276.

Gumbel CW Von (1874) Die palfiolithischen Eruptivgesteine des Fichtelgeberges. Franz, Munich

Wyman, D.A., Ayer, J.A., Conceicao, R.V., Sage, R.P., 2006, Mantle processes in an archean orogen: evidence from 2.67 Ga diamondbearing lamprophyres and xenoliths. Lithos, v. 89(3-4), pp. 300328. 


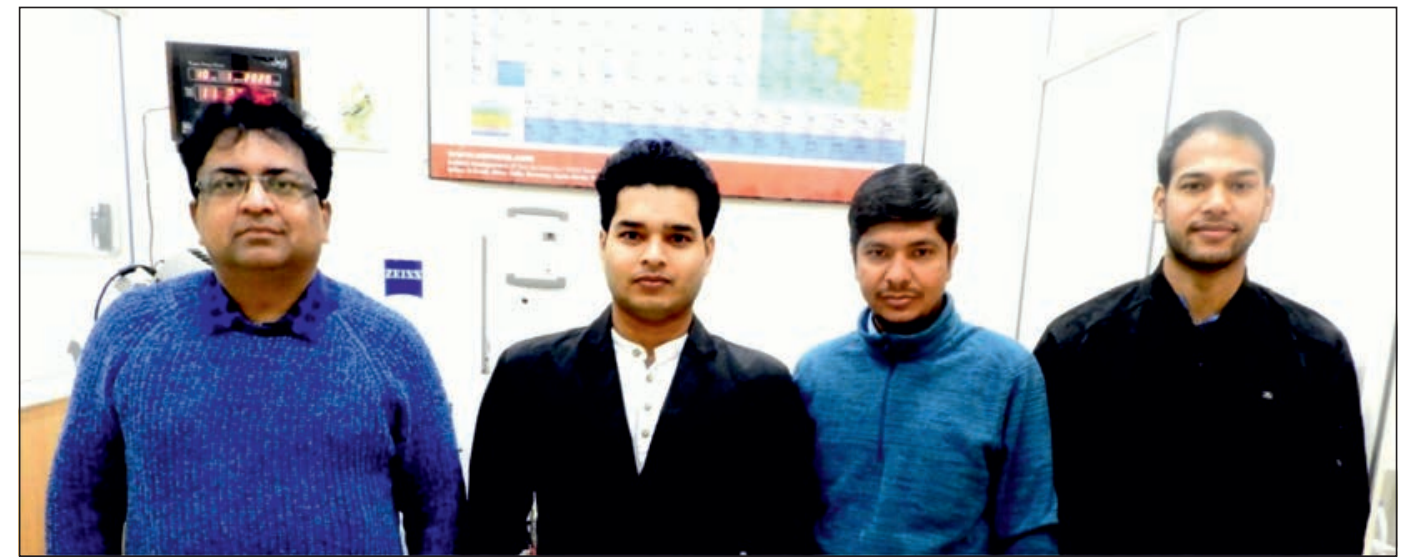

From left to right: N.V. Chalapathi Rao, Rohit Kumar Giri, Abhinay Sharma, and Ashutosh Pandey.

N.V. Chalapathi Rao is a Professor in the Department of Geology, Banaras Hindu University. He holds Ph.D. degrees from Osmania University and University of Cambridge. His research interests are in mineralogy, igneous petrology and geochemistry with special reference to alkaline rocks. He is a Fellow of the Indian National Science Academy, Indian Academy of Sciences, Andhra Pradesh and Telangana Science Academies and Alexander von Humboldt Foundation, Germany.

Rohit Kumar Giri is a Ph.D. scholar on UGC-JRF at the Department of Geology, Banaras Hindu University. He holds B.Sc (Hons.) and M.Sc (Tech.) in Geology from Banaras Hindu University and his research focuses on the petrogenesis of lamprophyres and lamproites.

Abhinay Sharma obtained B.Sc (Hons.) in Geology from the Dharanidhar Autonomous College, Keonjhar, Odisha and M.Sc (Tech.) in Geology from Banaras Hindu University. He is currently pursuing Ph.D. on kimberlites and ultramafics from Banaras Hindu University on a CSIR-JRF.

Ashutosh Pandey is pursuing Ph.D. at the Department of Geology, Banaras Hindu University as a SPM Fellow (CSIR). He holds B.SC (Hons.) and M.Sc (Tech.) in Geology from Banaras Hindu University. He is working on the genesis and geodynamic implications of the Precambrian alkaline rocks such as calc-alkaline lamprophyres, kimberlites and syenites. 